\title{
Tectonic Influences on Ground Water Quality: Insight from Complementary Methods
}

\author{
by Sam Earman ${ }^{1,2}$, Brian J.O.L. McPherson ${ }^{2,3}$, Fred M. Phillips ${ }^{4}$, Steve Ralser ${ }^{2,5}$, James M. Herrin 6,7 and James Broska ${ }^{8}$
}

\begin{abstract}
A study using multiple techniques provided insight into tectonic influences on ground water systems; the results can help to understand ground water systems in the tectonically active western United States and other parts of the world. Ground water in the San Bernardino Valley (Arizona, United States and Sonora, Mexico) is the main source of water for domestic use, cattle ranching (the primary industry), and the preservation of threatened and endangered species. To improve the understanding of ground water occurrence, movement, and sustainability, an investigation was conducted using a number of complementary methods, including major ion geochemistry, isotope hydrology, analysis of gases dissolved in ground water, aquifer testing, geophysics, and an examination of surface and subsurface geology. By combining information from multiple lines of investigation, a more complete picture of the basin hydrogeology was assembled than would have been possible using fewer methods. The results show that the hydrogeology of the San Bernardino Valley is markedly different than that of its four neighboring basins in the United States. The differences include water quality, chemical evolution, storage, and residence time. The differences result from the locally unique geology of the San Bernardino Valley, which is due to the presence of a magmatically active accommodation zone (a zone separating two regions of normal faults with opposite dips). The geological differences and the resultant hydrological differences between the San Bernardino Valley and its neighboring basins may serve as a model for the distinctive nature of chemical evolution of ground water in other basins with locally distinct tectonic histories.
\end{abstract}

'Corresponding author: Division of Hydrologic Sciences, Desert Research Institute, Reno, NV 89512; (775) 673-7415; fax: (775) 673-7363; searman@dri.edu

${ }^{2}$ Formerly at: Earth and Environmental Science Department, New Mexico Institute of Mining and Technology, Socorro, NM 87801.

${ }^{3}$ Department of Civil \&t Environmental Engineering, University of Utah, Salt Lake City, UT 84112.

${ }^{4}$ Earth and Environmental Science Department, New Mexico Institute of Mining and Technology, Socorro, NM 87801.

${ }^{5}$ Department of Geology \& Geophysics, University of WisconsinMadison, Madison, WI 53716.

${ }^{6}$ Chesapeake Energy Corporation, Oklahoma City, OK 73154.

7Formerly at: Petroleum Engineering Department, New Mexico Institute of Mining and Technology, Socorro, NM 87801.

${ }^{8}$ Branch of Water Resources, U.S. Fish and Wildlife Service, Albuquerque, NM 87103.

Received September 2007, accepted October 2007.

Copyright (C) 2008 The Author(s)

Journal compilation (c) 2008 National Ground Water Association.

doi: $10.1111 / j .1745-6584.2007 .00402 . x$

\section{Introduction}

Recent work (Newell et al. 2005; Earman et al. 2005) shows that tectonic activity can impact ground water systems, including the chemical composition of the water. Because many basins in the western United States and other parts of the world are located in tectonically active areas, understanding the role of tectonics in shaping ground water systems is important.

The San Bernardino Valley, in southeastern Arizona, United States, and northern Sonora, Mexico (Figure 1) is located in the Basin and Range physiographic province. Ground water in the basin is the only source for domestic supply and is critical to cattle ranching (the main revenue source for valley residents). Ground water is also used to maintain artificial streams and ponds in the San Bernardino National Wildlife Refuge (SBNWR; Figure 2A) that provide habitat for several species of endangered and threatened fishes. Ground water in the San Bernardino Valley is obtained almost exclusively from alluvial basin 


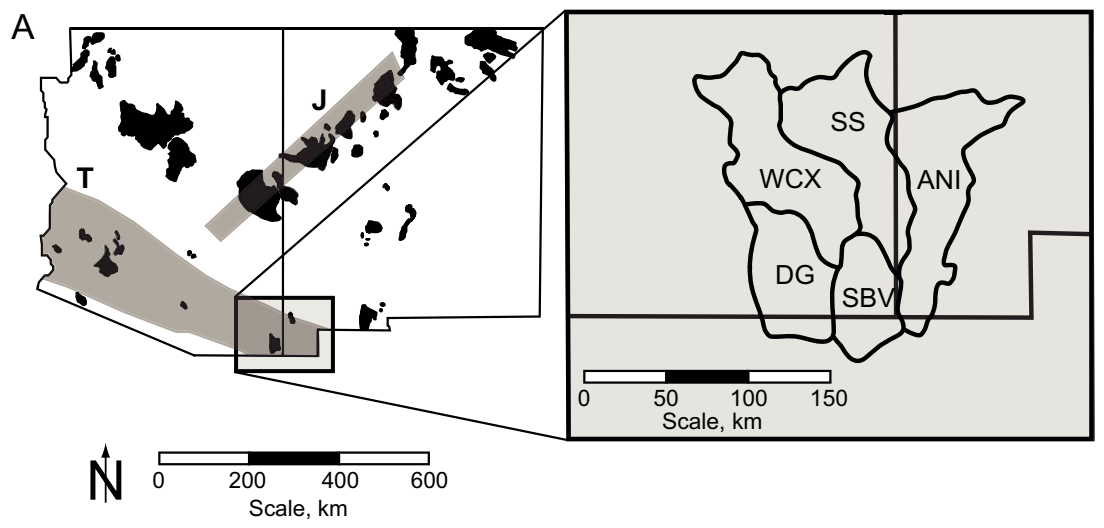

B

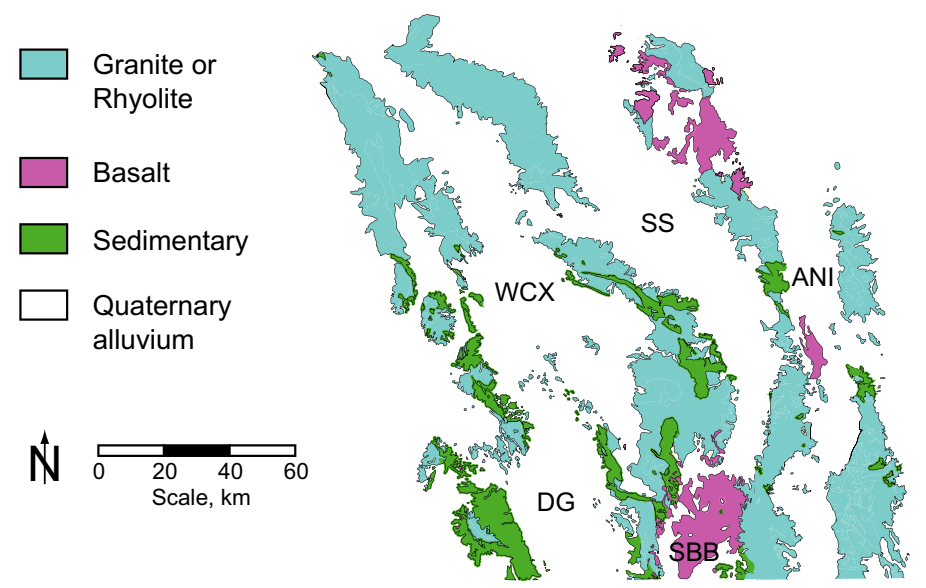

Figure 1. (A) Location of the San Bernardino Valley (SBV) and its neighboring basins. Left: map of Arizona and New Mexico showing areas of significant Cenozoic volcanism (after Aldrich and Laughlin 1984); gray bands indicate locations of regional structural lineaments (J: Jemez lineament, T: Texas lineament belt; lineament locations after Aldrich and Laughlin [1984] and Wertz [1970]). Right: zoom map showing basin boundaries SBV and its neighboring basins (DG = Douglas Basin, WCX = Willcox Basin, SS = San Simon subbasin of the Gila Basin, ANI = Animas Basin). (B) Generalized geologic map showing lithology of the San Bernardino Basin, its neighboring basins, and their bounding ranges (after Anderson et al. 1997; Hirschberg and Pitts 2000). The area covered by the map is bounded by latitudes $31^{\circ} 40^{\prime} \mathrm{N}$ and $33^{\circ} \mathrm{N}$ and longitudes $108^{\circ} 30^{\prime} \mathrm{W}$ and $111^{\circ} \mathrm{W}$.

fill; only two wells used for water production are known to penetrate consolidated rock beneath the alluvium. Any new pumping to supply the nearby towns of Douglas, Arizona and Agua Prieta, Sonora (1980 population 29,000; 2005 population $\sim 200,000$ ) has the potential to affect water availability. To gain a better understanding of ground water supply and its sustainability, especially with regard to maintaining endangered species habitat at the SBNWR, an investigation using a number of complementary methods (including major ion geochemistry, isotope hydrology, aquifer testing, geophysics, and an examination of surface and subsurface geology) was conducted; the results are discussed in the first part of this article.

An examination of the San Bernardino Valley's hydrogeology revealed that the basin's ground water characteristics (most notably water chemistry) differed markedly from those of water in the neighboring basins. Because the San Bernardino Valley and its four neighboring basins in the United States derive their fill from mountains of similar mineralogy, it seems unusual that water chemistry would vary so much between the San Bernardino Valley and its neighbors. Newell et al. (2005) and Earman et al. (2005) show that tectonic processes can influence water quality in the tectonically active western United States. Because lithologic differences between the source areas for basin fill cannot explain the difference in water chemistry, it was hypothesized that tectonic factors were the cause of the unique water chemistry in the San Bernardino Valley. An examination of this hypothesis is given in the second half of the article.

Although the water resources assessment and the examination of water chemistry are somewhat disparate topics, our work suggests that tectonic forces can affect both water chemistry and water supply. In addition, one of the goals of the special issue for which this article was prepared is to facilitate management and manipulation of arid basins to satisfy competing water quantity and water quality demands. As such, we present information on both water supply and water quality issues.

\section{Materials and Methods}

Water samples were collected from a number of wells and springs in the basin and from springs and streams in the surrounding highlands (Figure 2B; Table S1 and Table 1). Samples were analyzed for one or more 


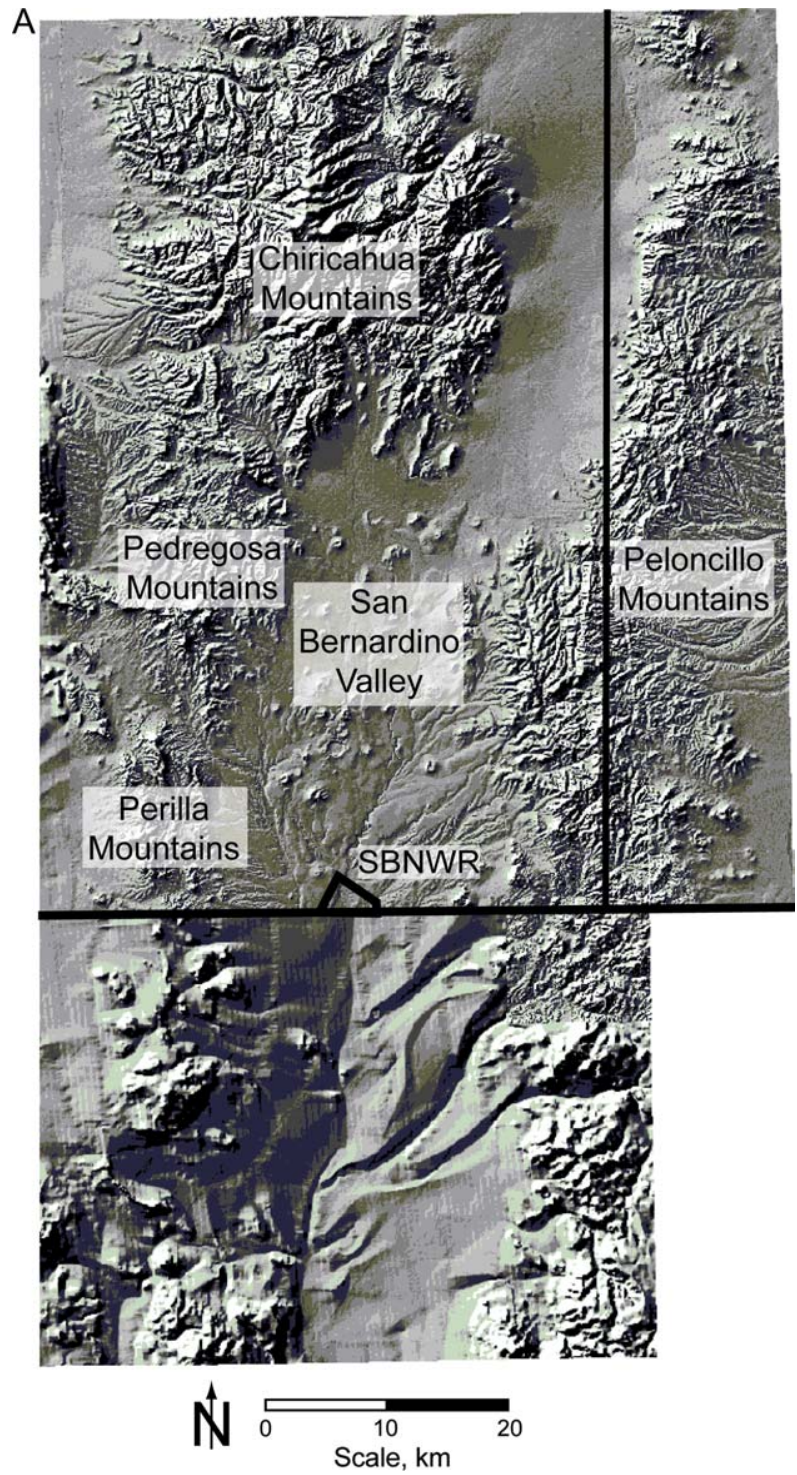

Figure 2. (A) Digital elevation hillshade of San Bernardino Valley and the surrounding areas. The boundary of the SBNWR is indicated by the triangle on the international border labeled "SBNWR"; horizontal line represents United States-Mexico border, vertical line represents Arizona-New Mexico border. (B) Locations of wells for which lithologic logs were available (light blue), locations of water samples collected for the study (red and yellow); wells used for the flowpath approximation are shown in yellow; in Table S1, the northernmost flowpath well is noted as "FP 1," and increasing numbers represent locations farther to the south. (C) Map showing hydraulic head contours for the main aquifer of the basin (brown, red, pink, and tan) and the shallow aquifer (blue-green). The extent the shallow aquifer is approximated by the contours for the shallow aquifer. Contour interval for the main aquifer is $20 \mathrm{~m}$ and interval for the shallow aquifer is $5 \mathrm{~m}$. (D) Generalized surface geology of the San Bernardino Valley and vicinity, after Biggs et al. (1999), Drewes (1980), and Dirección General de Geográfica del Territorio Nacional (1982). (E) Contours of Bouguer gravity anomaly; contour interval is 2 mgal.

of the following: $\delta^{18} \mathrm{O}$ and $\delta \mathrm{D}$, major ion chemistry, dissolved gas content, ${ }^{14} \mathrm{C}$ activity, $\delta^{13} \mathrm{C}$, and ${ }^{3} \mathrm{H}$ activity. In addition, parameters such as $\mathrm{pH}$, electrical conductivity (EC), and temperature were measured in the field at the time of sampling. Samples for ${ }^{14} \mathrm{C}$ activity and $\delta^{13} \mathrm{C}$ were collected from a set of wells picked to best approximate a flowpath from the Chiricahua mountains to the basin center (Figures $2 \mathrm{~B}$ and $2 \mathrm{C}$ ). $\delta^{18} \mathrm{O}$ and $\delta \mathrm{D}$ (relative to Vienna Standard Mean Ocean Water [VSMOW] values reported here are expressed in \%o relative to VSMOW such that the $\delta \mathrm{D}$ value of Standard Light Antarctic Precipitation is $-428 \%$ ) were determined via gas source mass spectrometry. All $\delta^{18} \mathrm{O}$ results were obtained via analysis of $\mathrm{CO}_{2}$ gas that had been equilibrated with a sample aliquot (Socki et al. 1992; Clark and Fritz 1997). All $\delta \mathrm{D}$ values were obtained by analyzing hydrogen gas formed during an oxidation-reduction reaction (Clark and Fritz 1997). During the initial portion of the study, a sample aliquot was reacted with zinc shavings at $450{ }^{\circ} \mathrm{C}$ for $30 \mathrm{~min}$ (Coleman et al. 1982); later, sample aliquots were reacted with powdered chromium at $750{ }^{\circ} \mathrm{C}$ for $60 \mathrm{~s}$ (Nelson and Dettman 2001). The change in methodology coincided with the transition to a new mass spectrometer. Multiple samples run using the old instrument and methodology were rerun for both $\delta^{18} \mathrm{O}$ and $\delta \mathrm{D}$ on the new instrument to ensure that values measured with the new instrument and methodology were identical within analytical error. Major ion chemistry samples were collected in clean, field-rinsed containers; one sample was collected in a 1-L container and left unpreserved, and a second sample (for metals analysis) of $250 \mathrm{~mL}$ was preserved in the field by addition of trace metal-grade nitric acid such that the $\mathrm{pH}$ was less than 2. Radiocarbon samples were collected via field precipiation (Clark and Fritz 1997), with approximately $75 \mathrm{~L}$ of water collected at each site. The $\mathrm{pH}$ of each sample was raised above 10 by addition of $\mathrm{NaOH}$, carbon was precipitated by addition of $\mathrm{BaCO}_{3}$, and flocculation of the precipitate was enhanced by addition of Percol 156. After being allowed to settle for at least $24 \mathrm{~h}$, the precipitate was collected and submitted for determination of ${ }^{14} \mathrm{C}$ activity by scintillation counting and $\delta^{13} \mathrm{C}$ by mass spectrometry (Clark and Fritz 1997). Dissolved gas samples were collected using passive diffusion samplers that were exposed to flowing source water for a minimum of $48 \mathrm{~h}$, allowing collection of duplicate gas samples in copper tubing that was sealed on site using a cold-weld tool. Precautions were taken to avoid atmospheric contamination during sample collection. Samples were analyzed via quadrupole mass spectrometer at the Dissolved Gas Lab of the University of Utah (for further description of sample collection and analysis procedures, see Manning [2002]). Bouguer gravity anomaly was measured with a Worden-type gravimeter, with compensation made for drift and influences from surrounding terrain. The data collected for this study were incorporated with data from Lynch (1972) and R. Keller (personal communication, 2001).

\section{Background}

\section{Climate}

In the San Bernardino Valley, average daily temperature ranges from about $14{ }^{\circ} \mathrm{C}$ to $16.5^{\circ} \mathrm{C}$, depending on altitude (Biggs et al. 1999; Hawley et al. 2000). 
B

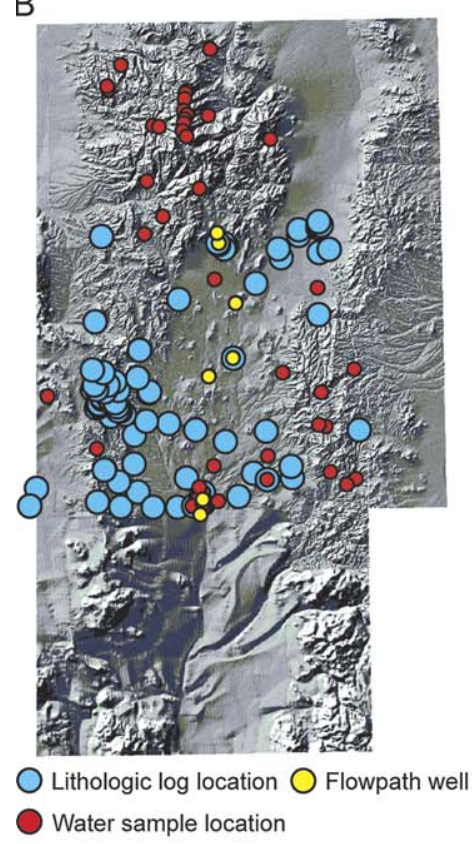

$\mathrm{D}$

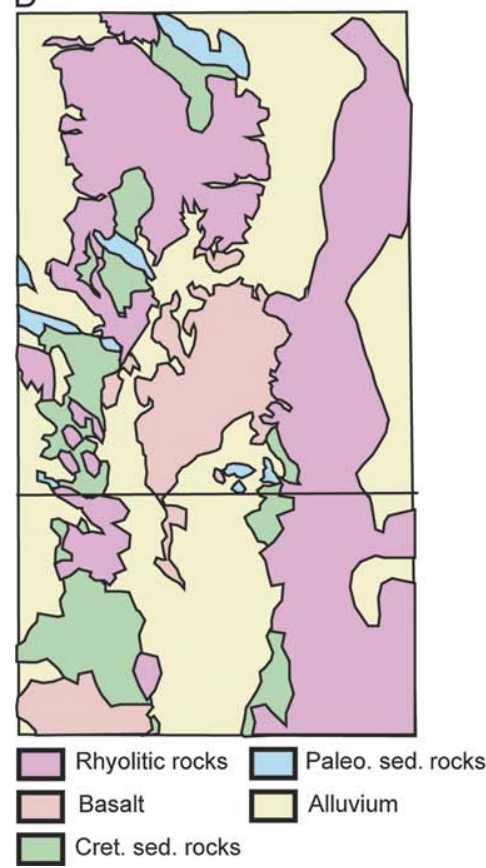

C

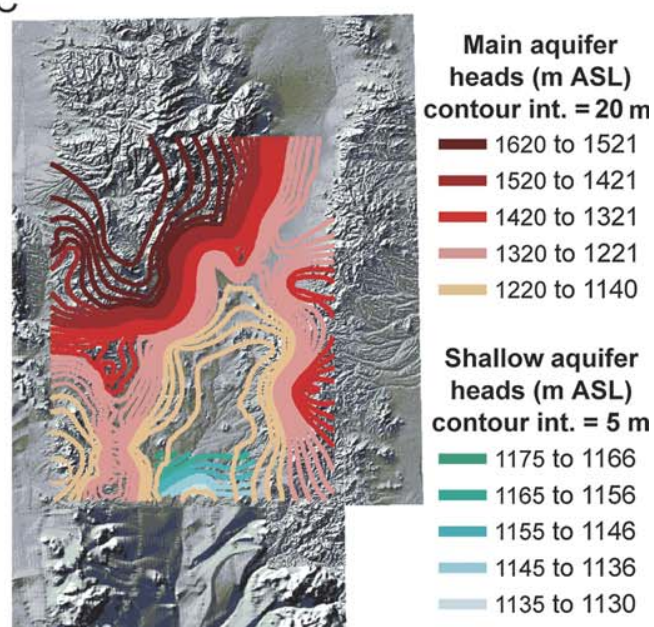

E

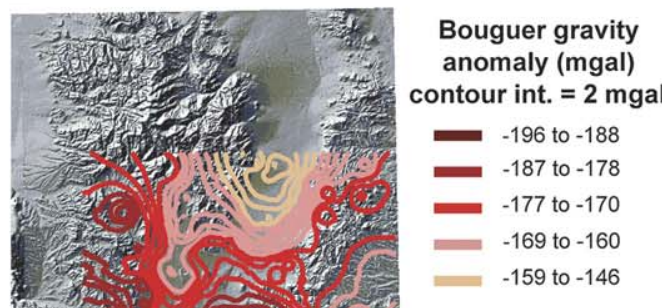

Figure 2. Continued.

According to the Western Regional Climate Center (http://wrcc.dri.edu), average annual precipitation varies from 200 to $410 \mathrm{~mm}$ depending on location. In the mountain ranges bounding the valley, precipitation can be as low as that observed in the basin (Perilla Mountains) to above $910 \mathrm{~mm} / \mathrm{year}$ in the Chiricahua Mountains.

\section{Likely Importance of Mountain Precipitation and Snow to Ground Water Recharge}

As described previously, the mountains bounding the valley receive significantly more precipitation than the valley floors. Because valley floors have low precipitation rates, high temperatures, and are inhabited by water- efficient desert plants, mountain precipitation provides much of the water for ground water recharge in many parts of the western United States. Although the majority $(\sim 70 \%)$ of mountain precipitation falls in the form of rain in the ranges surrounding the San Bernardino Valley, Wilson et al. (1980) provide a summary of rain and snow processes in western mountains and conclude that snow can be more important to recharge than suggested by its contribution to average annual precipitation. Most rain in this area falls in relatively brief but intense monsoonal storms during the summer, while infiltration from snowmelt occurs as a fairly uniform pulse in the spring. This allows wetting of the soil to be followed by further infiltration in the case of snowmelt, while the soil will dry between 
Table 1

Stable Isotope Content of Water from the San Bernardino Valley and Vicinity

\begin{tabular}{|c|c|c|c|c|}
\hline Water Source & $\delta^{18} \mathbf{O}(\%)$ & $\delta \mathbf{D}(\%)$ & Elevation (m) & MRCE (m) \\
\hline \multicolumn{5}{|l|}{ Chiricahua springs and creeks } \\
\hline Ash Spring & -10.2 & -71 & 1890 & 2825 \\
\hline Barfoot Spring & -9.2 & -65 & 2512 & 2685 \\
\hline Bear Wallow Spring & -10.0 & -65 & 2841 & 2947 \\
\hline Booger Spring & -9.6 & -67 & 2816 & 2917 \\
\hline Cave Creek & -9.7 & -65 & - & - \\
\hline Cima Creek & -9.7 & -67 & - & - \\
\hline Cottonwood Corral Spring & -8.7 & -66 & 1850 & 2134 \\
\hline Hillside Seep & -9.9 & -64 & 2682 & 2835 \\
\hline Hillside Spring & -10.2 & -68 & 2682 & 2835 \\
\hline Krentz Spring & -8.9 & -69 & 1707 & 2012 \\
\hline Lower Rustler Spring & -10.5 & -65 & 2551 & 2743 \\
\hline Mormon Spring & -10.4 & -70 & 2039 & 2926 \\
\hline Ojo Agua Fria & -9.9 & -69 & 2752 & 2944 \\
\hline Onion Saddle Seep & -9.1 & -67 & 2316 & 2438 \\
\hline Price Spring & -10.1 & -64 & 1902 & 2737 \\
\hline Pumphouse Spring & -9.0 & -66 & 1670 & 2177 \\
\hline SWRS Upper Spring & -8.9 & -66 & 1673 & 2177 \\
\hline Sycamore Spring & -9.0 & -65 & 1875 & 2073 \\
\hline Tub Spring & -10.5 & -67 & 2778 & 2947 \\
\hline Turkey Creek (East) & -9.6 & -66 & - & - \\
\hline Turkey Creek (West) & -10.0 & -67 & - & - \\
\hline Upper Rustler Spring & -10.4 & -72 & 2586 & 2743 \\
\hline Welch Seep & -10.2 & -68 & 1975 & 2804 \\
\hline Anita Spring & -10.8 & -70 & 2835 & 2975 \\
\hline Birdsong Spring & -10.6 & -67 & 2250 & 2737 \\
\hline Sulphur Spring & -10.9 & -79 & 1533 & 2469 \\
\hline Turkey Seep & -9.7 & -64 & 1902 & 2986 \\
\hline \multicolumn{5}{|l|}{ San Bernardino Springs } \\
\hline Black Draw & -7.8 & -63 & - & - \\
\hline House Spring & -7.4 & -62 & - & - \\
\hline Mesa Seep 2 & -8.3 & -57 & - & - \\
\hline Tule Spring & -8.7 & -61 & - & - \\
\hline \multicolumn{5}{|l|}{ San Bernardino Wells } \\
\hline Austin 2 & -8.6 & -67 & - & - \\
\hline Peterson 3 & -7.7 & -60 & & \\
\hline \multicolumn{5}{|l|}{ San Bernardino precipitation } \\
\hline Overnight precipitation & -6.4 & -48 & - & - \\
\hline SB precipitation 1-99 & -7.5 & -55 & - & - \\
\hline SB precipitation $3-00$ & -6.7 & -51 & - & - \\
\hline SB precipitation $1-01$ & -7.4 & -43 & - & - \\
\hline SB precipitation 1-02 & -7.7 & -46 & - & - \\
\hline \multicolumn{5}{|l|}{ Perilla Mountains Springs } \\
\hline Lower Tincup Spring & -7.9 & -54 & - & - \\
\hline \multicolumn{5}{|l|}{ Peloncillo mountains springs } \\
\hline Baker Spring & +4.5 & -12 & - & - \\
\hline Eicks Spring & -8.1 & -53 & - & - \\
\hline Geronimo Tank & +6.6 & +1 & - & - \\
\hline Green Wash & -7.3 & -55 & - & - \\
\hline Hadley Pond & +14.3 & +30 & - & - \\
\hline Wash Seep & -4.3 & -45 & - & - \\
\hline
\end{tabular}

rain events. In addition, the input of water from snowmelt occurs when potential evapotranspiration is low because temperatures are cool and vegetation is dormant; rainfall more typically occurs when temperatures are high and vegetation is active, leading to high potential evapotranspiration. 
Geology

\section{Surrounding Mountain Ranges}

The ranges bounding the San Bernardino Valley are predominantly rhyolitic in composition; rhyolitic tuff and rhyolite are the most common units found in these ranges (Figure 2D). In addition to the igneous rocks, there are a number of Cretaceous and Paleozoic sedimentary units present; these rocks are primarily carbonates, predominantly limestone (Drewes 1980).

\section{San Bernardino Valley}

The San Bernardino Valley's formation is the result of Basin and Range tectonic activity from the early Oligocene through the present (Lynch 1972; Drewes 1981). The fill material in the basin is primarily composed of alluvial material, but the southern two-thirds of the northern portion of the basin (we define the "northern portion" of the basin as extending from the northern boundary of the basin to $\sim 8 \mathrm{~km}$ south of the international border) contains significant basalts, as shown both by lithologic logs (Figure 2B) and surface mapping (Drewes 1980; Dirección General de Geográfica del Territorio Nacional 1982; Biggs et al. 1999).

Nearly all the alluvial material in the basin fill is derived from the mountains bounding the basin; reflecting the composition of these ranges, it is predominantly rhyolitic, but some zones received sediment from montane sedimentary units and thus contain significant proportions of carbonate minerals (Drewes 1980; du Bray et al. 1997; Biggs et al. 1999). Numerous clay deposits derived from weathering of the basaltic or rhyolitic sediments are present in the basin fill. In addition to small deposits from local weathering, a lacustrine clay unit is present in the subsurface near the basin center (Longsworth 1991; Davis et al. 1997).

The valley floor basalts range in age from 3.6 to 0.26 million years $(\mathrm{Ma})$ (there are older basalts on the flanks of bounding mountain ranges as old as $9 \mathrm{Ma}$ ); they cover an area of approximately $850 \mathrm{~km}^{2}$ at the surface, but most individual flows cover less than $5 \mathrm{~km}^{2}$. The younger basalt flows are typically less than $3 \mathrm{~m}$ thick, but the older basalts tend to be present in thicker deposits (Lynch 1972). Well logs show that basalts are common as interbeds in the basin fill in the southern two-thirds of the northern portion of the basin.

In the majority of the San Bernardino Valley, the main aquifer of the basin is a single, unconfined basin-fill aquifer. The lacustrine clay near the basin center serves as a confining unit for a small portion of the main aquifer (a number of flowing artesian wells are present in the area near the international border) and also forms the base of a shallower, unconfined aquifer. In the remainder of this article, unless specific mention to the contrary is made, all mentions of ground water or an aquifer will be referring to the main aquifer and/or the water it contains.

\section{Hydrogeology}

\section{Basin Structure}

The structure of the basin was analyzed by examining the surficial geology (Figure 2D, based on Drewes
1980; Dirección General de Geográfica del Territorio Nacional 1982; Biggs et al. 1999); subsurface lithology (using well logs obtained from the Arizona Department of Water Resources and the Arizona Oil and Gas Conservation Commission, Figure 2B); descriptions of basin structure (from Drewes 1980, 1981; Biggs et al. 1999); the Bouguer gravity anomaly (Figure 2E); and hillshades of digital elevation models.

Based on our interpretation of these data, the northern portion of the basin is a half graben dipping to the west, while the southern portion is a half graben dipping to the east (Figure 3). Our analysis shows the San Bernardino Basin is offset from the San Simon Basin to the north by a transfer fault (a strike-slip fault that facilitates the transfer of strain between two extended domains that share a common strike but are offset), and the west-dipping half graben in the northern portion of San Bernardino Valley is split into "mini-half grabens" by four other transfer faults. All five transfer faults strike NW-SE, aligned with the regional structural lineament intersecting the basin (Figure 1A). The area separating the northern and southern portions of the basin is a boundary in three senses: it separates two bedrock dip domains, it separates an area that experienced significant basaltic volcanism in the Cenozoic from an area that has experienced minimal basaltic volcanism, and it separates an area with distinct NW-SE transfer faults from an area lacking such features.

This boundary is an accommodation zone, defined by Faulds and Varga (1998) as a belt "of overlapping fault terminations [that] can separate either systems of uniformly dipping normal faults or adjacent domains of oppositely dipping normal faults." Based on the geometry of the San Bernardino accommodation zone, it is classified as an oblique antithetic anticlinal accommodation zone using Faulds and Varga's (1998) terminology. Stewart et al. (1998) identify more than 60 accommodation zones in the western United States; more than two-thirds of the accommodation zones identified in the Basin and Range Province are associated with major volcanic fields (Faulds and Varga 1998). The fact that the San Bernardino accommodation zone marks the southern boundary of widespread basaltic volcanism suggests that the basalts are related to the accommodation zone; therefore, the accommodation zone is described as "magmatically active."

\section{Ground Water Source Areas}

\section{Contribution of Bounding Ranges and Valley Floor Precipitation}

Stable isotope data from the mountain ranges surrounding the San Bernardino Valley, valley floor precipitation, and wells and springs located on the San Bernardino Valley floor are shown in Figure 4. Water from the Chiricahua Mountains is the most isotopically depleted, as expected based on their high elevation (maximum of $2975 \mathrm{~m}$ above sea level [asl]) compared to the other ranges (maximum elevations of 1966, 1993, and $1947 \mathrm{~m}$ asl for the Peloncillo, Pedregosa, and Perilla ranges, respectively).

Some Peloncillo waters have undergone significant evaporation, likely due to the fact that some of the samples were collected during a drought, and, as a result, 


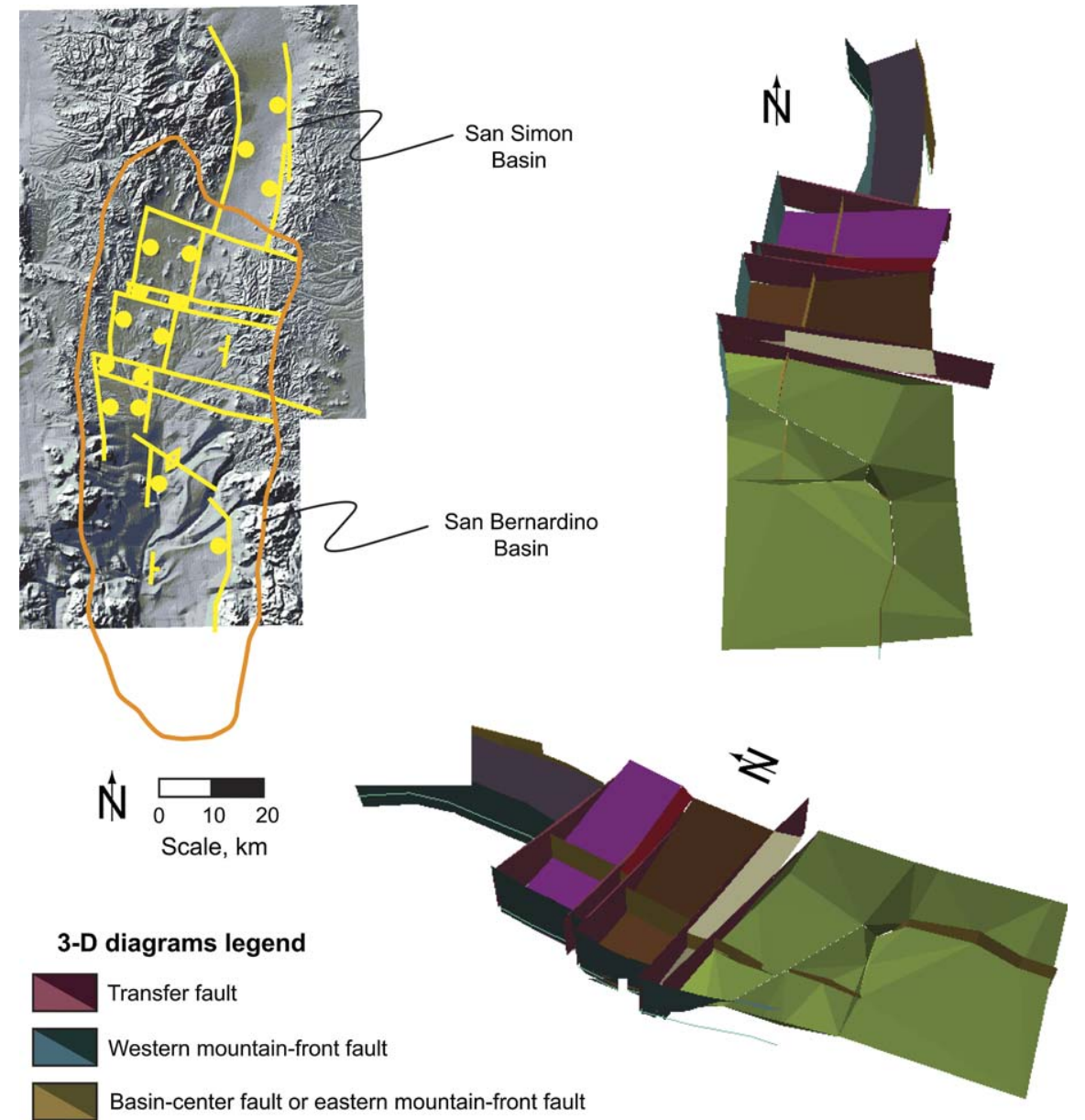

Figure 3. Structural model of the San Bernardino Basin and southern San Simon Basin. Diagram on left shows the San Bernardino hydrologic basin Boundary (which extends beyond range-front faults) in orange. Faults are shown in yellow; normal faults are shown with bar and ball on downthrown side, and transfer faults are represented by plain lines. The anticline (showing the location of the accommodation zone) is indicated via a line with arrowheads. Note the NW-SE orientation of the transfer faults parallel to that of the Texas Lineament Belt (Figure 1A). Diagrams on right show different views of a three-dimensional model of basin bedrock structure, with vertical exaggeration of 4.5 . The scale bar shown is common to all three diagrams; orientation is indicated by an individual north arrow for each diagram. Colors used in the 3D structural diagrams not shown on the legend symbolize individual mini-half grabens.

only stagnant pools were available for sampling rather than flowing spring water. The less-evaporated Peloncillo samples and the intercept of the global meteoric water line and the local evaporation line (the best-fit line for the Peloncillo samples that have undergone evaporation, slope $=3.8$; Figure 4 ) show that unevaporated Peloncillo water is slightly lighter than valley floor precipitation. Only one mapped spring in the Perilla Mountains had water present during sampling. It is slightly lighter than the intersection of the Peloncillo fit line with the global line.

Well water from the main aquifer overlap with the heaviest samples from the Chiricahua Mountains, suggesting that the Chiricahuas are the main recharge area for the aquifer. Two of the main aquifer wells (Snure Well and Peterson Well 3) are anomalously enriched; they are both located near losing ephemeral stream channels, and Snure Well is also close to a fault (Biggs et al. 1999), both of which could provide focused recharge of isotopically heavy valley floor precipitation that could mix with high-elevation recharge water in the aquifer, thus enriching the isotope signature. Most spring waters from the valley floor (springs occur near the basin center, in the area where both the main aquifer and the shallow aquifer are present) are more enriched than well water. All the enriched springs appear to have undergone one of two processes to yield the enriched signature: either the water has experienced evaporation prior to sampling or the discharge is a mix between high-elevation recharge and valley floor precipitation. The mean value of the $\delta^{18} \mathrm{O}$ of main aquifer water from wells in the area where the springs are located (near the basin center) is $-9.19 \%$ and the mean value for valley floor precipitation is $-7.24 \%$. Nonevaporated spring $\delta^{18} \mathrm{O}$ values range from $-9.23 \%$ to $-8.37 \%$. Given the analytical uncertainty in $\delta^{18} \mathrm{O}$ analyses, the low end of the spring water range is isotopically indistinguishable from the main aquifer water, suggesting that the lightest shallow aquifer water is composed entirely of high-elevation recharge (this water likely reaches the shallow aquifer via some combination of lateral flow and leakage across the confining unit). The isotopically heavy shallow aquifer water represents 
A

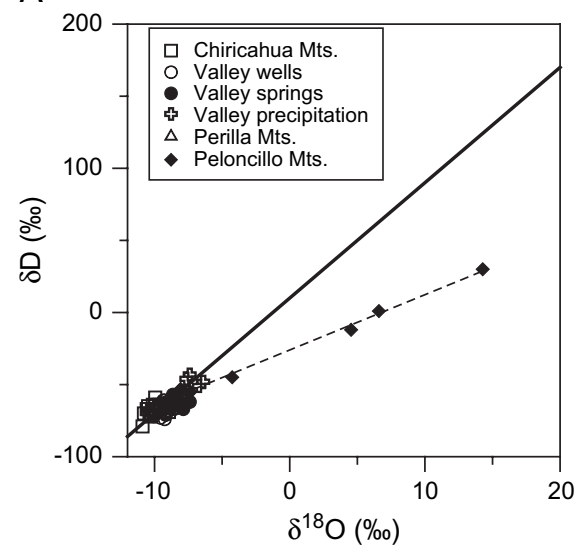

B

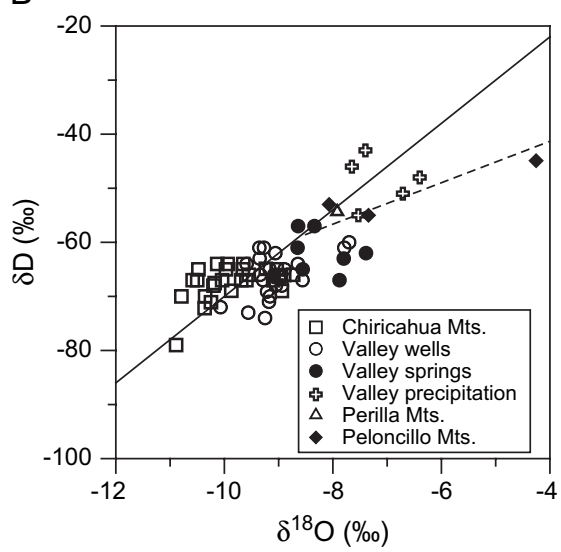

Figure 4. Plots showing stable isotope composition of water from the San Bernardino Valley and vicinity, shown with the global meteoric water line (solid) and a best-fit line for water from the Peloncillo Mountains, showing a slope of 3.8 for evaporated water from the range. (A) Includes data for highly evaporated water from the Peloncillo Mountains. (B) Highly evaporated Peloncillo water is excluded from this plot so that other water can be seen more clearly.

a mixture of high-elevation precipitation from the bounding mountain ranges and valley-floor precipitation.

Endmember mixing calculations were used to estimate the relative contribution of mountain and valleyfloor precipitation to spring discharge. In this model, if the isotopic composition of a mixture $(z)$ and the two endmember waters that combine to form it is known ( $x$ and $y$, respectively), then the proportions of the endmembers that created the mixture ( $a$ and $b$, respectively) can be determined (assuming $x \neq y$ ) by solving the series of equations $a x+b y=z ; a+b=1$. Results show that the valley-floor recharge accounts for at most $40 \%$ of springflow. The range in valley-floor precipitation contribution from $0 \%$ to $40 \%$ suggests that local recharge occurs preferentially in certain areas; with the available data, no correlation could be made between specific geologic features and increased valley-floor recharge contribution.

\section{Relative Contribution of Bounding Mountain Ranges}

An endmember mixing model was used to estimate the proportion of San Bernardino ground water derived from the Chiricahuas vs. the other bounding ranges. The mean $\delta^{18} \mathrm{O}$ of the Chiricahua ground water $(-9.84 \%$ o was used as one endmember of the mix. A $\delta^{18} \mathrm{O}$ of $-7.99 \%$ was used for the other ranges, based on the intersection of the evaporation line for the Peloncillo ground water with the global meteoric water line. The Peloncillo value was used because only one sample from the Perilla and Pedregosa ranges was obtained; this sample appears to have undergone significant evaporation and may also have been affected by fractionation due to freezing. Since the Perillas and Pedregosas are essentially the same elevation as the Peloncillos (the spread in maximum elevation for the three ranges is only $46 \mathrm{~m}$ ), we assume that the Peloncillo value is representative for all three ranges. The mean $\delta^{18} \mathrm{O}$ value of water from the main aquifer is $-9.21 \%$ (this excludes all springs; Magoffin Well, which samples the bedrock of the basin; and Snure and Peterson 3 wells, which are influenced by mixing with valley-floor precipitation), so mass balance calculations based on the means suggest that $66 \%$ of the recharge to the main aquifer is derived from the Chiricahua Mountains, with the other ranges providing 34\%. To assess the uncertainty of this estimate, endmember calculations using the mean \pm 1 standard deviation for both Chiricahua water and San Bernardino main aquifer water were performed, showing that Chiricahuas contribute between $48 \%$ and $99 \%$ of the recharge to the San Bernardino Valley. Valley-floor precipitation appears to be of importance only in limited zones of the main aquifer where focused recharge can occur; even in these zones, it is less important than water that originated as precipitation falling on the bounding mountain ranges.

\section{Ground Water Recharge Elevations and Sources}

Because water from the Chiricahuas is so important to the basin aquifer, a greater understanding of the Chiricahua contribution was desired. Determining the contribution of snowmelt vs. rain and high-elevation precipitation vs. low-elevation precipitation is important not only for understanding the processes in the Chiricahuas but might also yield insight into similar processes in other mountainbasin systems of the western United States.

Comparing stable isotope content of Chiricahua spring water to the spring orifice elevation yielded a general trend of isotopically lighter water at higher elevations, but the correlation was poor $\left(r^{2}=0.12\right)$. Comparing the stable isotope content of spring water to the maximum recharge elevation for that spring (the highest elevation in the surface drainage in which the spring is located) improved the $r^{2}$ value to 0.50 ; removing four outlier values from the original data set $(n=27$; Table 1$)$ yielded a much better correlation $\left(r^{2}=0.72\right.$; Figure 5). The elevation associated with the mean Chiricahua ground water of $-9.29 \%$ on the best-fit line in Figure 4 suggests that precipitation that falls at about $2300 \mathrm{~m}$ is the main source of recharge for the basin water (note that this is not described as a "recharge elevation," as stable isotope data can suggest only the zone in which precipitation fell, not the zone in which it actually became recharge). 


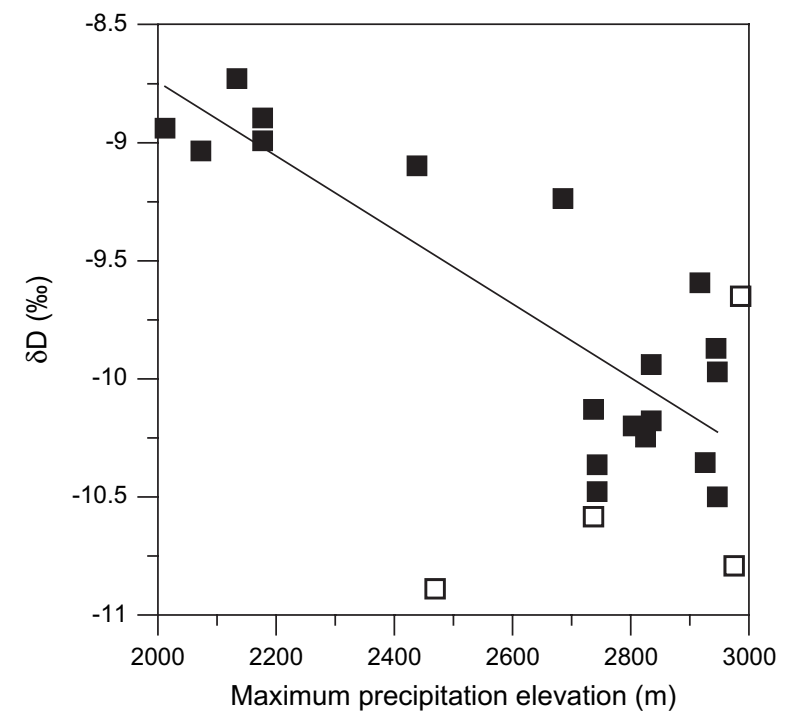

Figure 5. Plot showing $\delta^{18} \mathrm{O}$ of spring water and surface water in the Chiricahua Mountains as a function of the highest elevation in the watershed from which the sample was taken. Data are shown in Table 1; the four samples represented by hollow symbols are outliers that were not used to calculate the best-fit line shown on the plot.

However, several factors complicate estimation of precipitation elevation.

First, determining the elevation associated with a mean ground water $\delta^{18} \mathrm{O}$ value should yield a mean elevation of precipitation rather than an absolute elevation. The range of values for main aquifer water suggests a range in possible elevation of 2080 to $2500 \mathrm{~m}$, based on the mean value for San Bernardino ground water \pm 1 standard deviation. Second, ground water in the basin is derived not only from the Chiricahuas but also the other bounding ranges, which yield water with heavier isotope signatures due to their relatively low elevations. Finally, most basin ground water appears to have been influenced by evaporation at some point prior to sampling. The second and third issues suggest that estimates of precipitation elevation for recharge in this system are likely to be underestimates.

The relationship between season and isotope content of precipitation at a given location is well recognized and has been used to estimate the proportion of recharge derived from snowmelt and rain (e.g., Maulé et al. 1994; Winograd et al. 1998; Mariner and Nimz 2000). Earman et al. (2006) use an endmember mixing model and stable isotope compositions of snowmelt, rain, and ground water to demonstrate that approximately $60 \%$ of ground water recharge in the Chiricahuas is composed of snowmelt. Although this proportion may seem high in light of the proportions of water equivalent that fall as rain and snow in the Chiricahuas ( 25\% snow and $75 \%$ rain, assuming $10 \%$ water equivalence per unit depth of snow), as discussed in the Background section, a theoretical consideration of the recharge process in western mountains suggests that snowmelt should have a stronger influence on recharge than suggested by the portion of precipitation composed of snow. In addition, several studies (e.g.,
Simpson et al. 1972; Winograd et al. 1998; Earman et al. 2006) show that snowmelt has similar seemingly large contributions to recharge at several sites around the western United States, based on the proportion of average annual precipitation for which it accounts.

\section{Ground Water Ages}

Ground water ages were estimated using ${ }^{14} \mathrm{C}$ and $\delta^{13} \mathrm{C}$ data from the wells approximating a flowpath through the basin. Because reactions such as carbonate dissolution and isotope exchange with the aquifer matrix can affect the ${ }^{14} \mathrm{C}$ activity of water, the computer code NETPATH (Plummer et al. 1991) was used to estimate ground water ages while taking into account nondecay geochemical processes that have the potential to influence the radiocarbon activity.

The NETPATH-calculated ages are shown in Table S1. In general, the ages show a logical progression from younger to older as distance along the flowpath approximation increases, but the age of water from flowpath well 2 (900 years) is less than the flowpath well 1 upgradient (1500 years). This is an artifact of the imperfect nature of the flowpath approximation. The total depth of flowpath well 1 is $190 \mathrm{~m}$ greater than that of flowpath well 2, and the difference in elevation above sea level for the maximum depth of the two wells is $90 \mathrm{~m}$. Water on the shallower flowpath was recharged more recently than that on the deeper flowpath, causing the apparently anomalous age of flowpath well 2. Budget constraints precluded drilling wells to allow sampling along a true flowpath, but the major ion and isotope data suggest that the flowpath approximation is reasonable.

The ground water ages for the wells along the flowpath were used to determine travel time between pairs of neighboring wells. By assuming an effective porosity value of 0.25 , using observed distance between wells, observed hydraulic gradient between wells, and the calculated travel time between wells to estimate ground water velocity, a form of Darcy's Law could be solved for $K$. This approach is similar to the use of ${ }^{14} \mathrm{C}$ ages to estimate hydraulic conductivity by Phillips et al. (1989) and Plummer et al. (1990). Values obtained using this method range from $1 \times 10^{-6}$ to $1 \times 10^{-4} \mathrm{~m} / \mathrm{s}$, with a geometric mean value of $1 \times 10^{-5} \mathrm{~m} / \mathrm{s}$ (Earman 2004). Although there is some uncertainty in these estimates because of possible error in ${ }^{14} \mathrm{C}$ sample collection and data analysis and the fact that the flowpath wells are an imperfect approximation of a flowpath, these variations are on the same order as those associated with conventional aquifer pumping tests.

\section{Chemical Evolution of Ground Water}

The chemical signatures of water from the San Bernardino aquifer and lower Chiricahuas are shown in Figure 6A. Water near the northern edge of the basin has chemical signatures $\left(\mathrm{Ca}^{2+}-\mathrm{HCO}_{3}^{-}\right)$similar to those of low-elevation springs in the Chiricahuas. As water moves downgradient, the anion signature remains unchanged ( $\mathrm{HCO}_{3}^{-}$dominated), but the cation signature shifts from $\mathrm{Ca}^{2+}$ dominated to a mixed-ion water, with greatly increased proportions of $\mathrm{Na}^{+}$and $\mathrm{Mg}^{2+}$. Spring water 


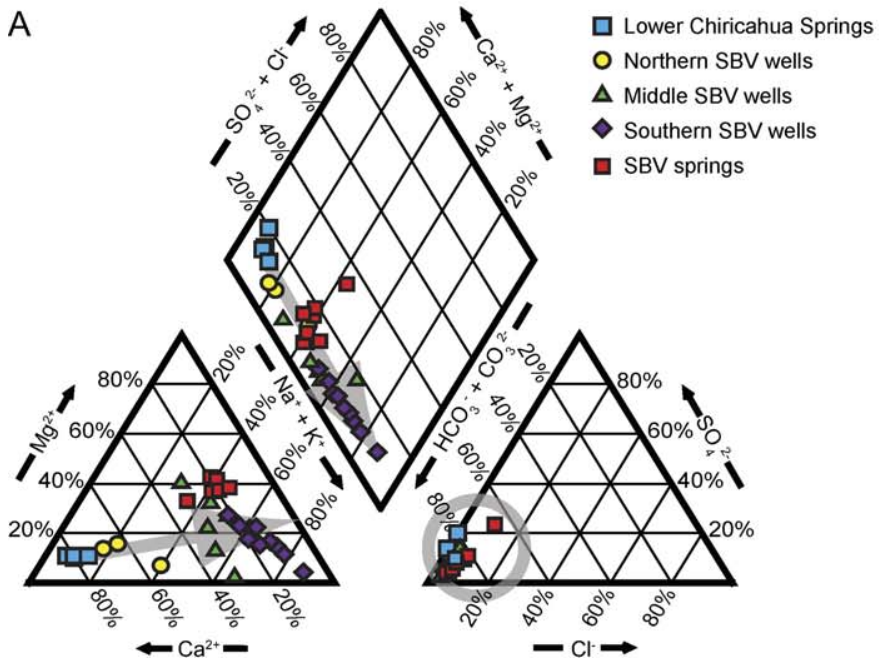

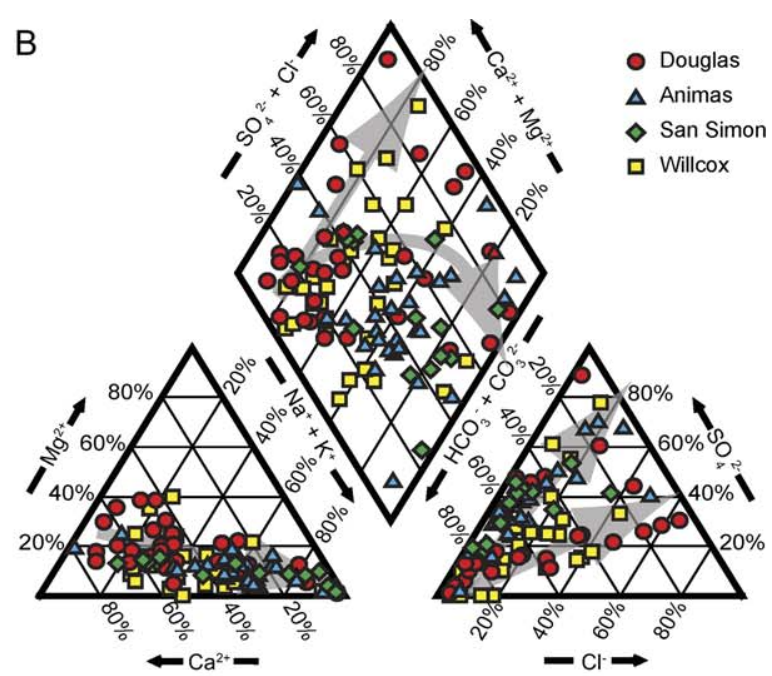

Figure 6. Piper diagrams showing chemical evolution of water in the San Bernardino Valley (A) and its neighboring basins (B).

from the valley floor (which occur in the area where the shallow aquifer is present) is similar in chemical composition to water from the main aquifer but contains higher proportions of $\mathrm{Mg}^{2+}$.

Processes controlling the chemical evolution of San Bernardino ground water are discussed in detail by Earman et al. (2005). The chemical evolution follows two distinct patterns, as shown in Figure 7. On the initial portion of the flowpath (wells 1 through 3 ), there is a linear relationship between $\mathrm{HCO}_{3}^{-}$and $\mathrm{Ca}^{2+}$, with increases in $\mathrm{HCO}_{3}^{-}$concentration accompanied by increases in $\mathrm{Ca}^{2+}$ concentration; on the latter portion of the flowpath, the concentration of $\mathrm{HCO}_{3}^{-}$increases without any concomitant increase in $\mathrm{Ca}^{2+}$ concentration. On the initial segment of the flowpath, basalts are not present in the basin fill and sediment is derived from a portion of the

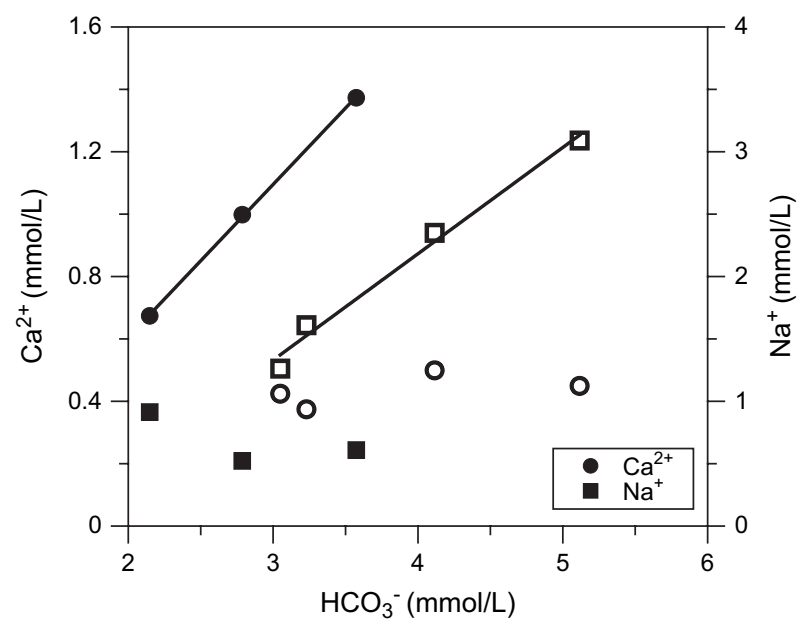

Figure 7. Plot showing calcium concentration (circles; left $y$-axis) and $\mathrm{Na}^{+}$concentration (squares; right $\boldsymbol{y}$-axis) vs. $\mathrm{HCO}_{3}^{-}$concentration for ground water on the flowpath through the San Bernardino aquifer. Solid symbols represent points on the initial portion of the flowpath and hollow symbols represent points on the latter portion of the flowpath. bounding ranges that contains a high proportion of carbonates. As a result, incongruent dissolution of calcite and dolomite (producing $\mathrm{Ca}^{2+}, \mathrm{Mg}^{2+}$, and $\mathrm{HCO}_{3}^{-}$) is the dominant control on water chemistry (Earman et al. 2005).

The chemical evolution on the latter part of the flowpath (where increases in $\mathrm{HCO}_{3}^{-}$concentration are not accompanied by increases in $\mathrm{Ca}^{2+}$ concentration) is driven by the input of magmatic $\mathrm{CO}_{2}$ (Earman et al. 2005). The relationship between helium isotope ratios in dissolved gas from San Bernardino ground water and $\mathrm{HCO}_{3}^{-}$concentration is shown in Figure 8 . The value " $R$ " represents the ratio of ${ }^{3} \mathrm{He}$ to ${ }^{4} \mathrm{He}$ for the dissolved gas extracted from a given water sample, and " $R_{\mathrm{a}}$ " is the ${ }^{3} \mathrm{He} /{ }^{4} \mathrm{He}$ ratio of the atmosphere. High values of the ratio

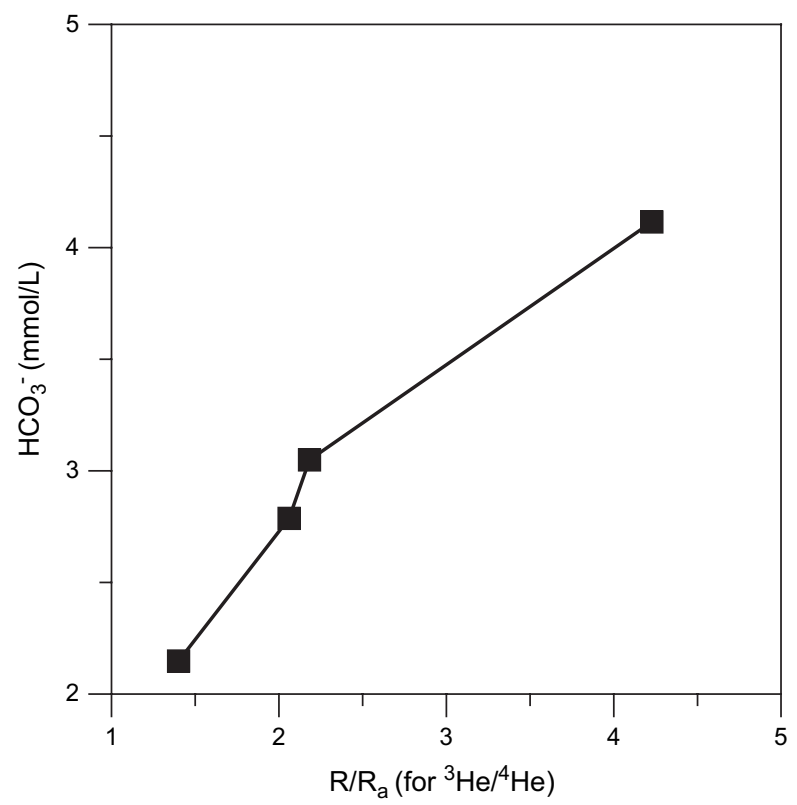

Figure 8. Plot showing concentration of $\mathrm{HCO}_{3}^{-}$as a function of $R / R_{\mathrm{a}}$ for ${ }^{3} \mathrm{He} /{ }^{4} \mathrm{He}$. Increases in both $\mathrm{HCO}_{3}^{-}$and $R / R_{\mathrm{a}}$ coincide with increasing distance along the flowpath. 
$R / R_{\mathrm{a}}$ for ${ }^{3} \mathrm{He} /{ }^{4} \mathrm{He}$ are diagnostic of injection of mantle $\mathrm{He}$ (Oxburgh et al. 1986). The increase in $R / R_{\mathrm{a}}$ values along the flowpath (Table S1), although not direct evidence of $\mathrm{CO}_{2}$ injection, is direct evidence that magmatic gas is being added to the aquifer; $\mathrm{CO}_{2}$ is almost always the main component of magmatic outgassing (White and Waring 1963; Mao et al. 2002). Input of magmatic $\mathrm{CO}_{2}$ causes $\mathrm{HCO}_{3}^{-}$concentration to increase via two mechanismsdissolution of $\mathrm{CO}_{2}$ followed by conversion to $\mathrm{HCO}_{3}^{-}$ (given that the $\mathrm{pH}$ of San Bernardino water ranges from 6.7 to 8.3 , nearly all magmatic $\mathrm{CO}_{2}$ that dissolves will be converted to $\mathrm{HCO}_{3}^{-}$) and by providing a needed reactant for weathering of basin alluvium by silicate hydrolysis (Earman et al. 2005). Increases in $\mathrm{Na}^{+}$over the latter part of flowpath are driven by silicate hydrolysis of rhyolitic minerals (Earman et al. 2005), as shown by concomitant increases in $\mathrm{HCO}_{3}^{-}$(Figure 7). The processes dominating the evolution of water chemistry on both the initial portion of the flowpath (incongruent dissolution of carbonate minerals) and the latter portion of the flowpath $\left(\mathrm{CO}_{2}\right.$ injection/silicate hydrolysis driven by $\mathrm{CO}_{2}$ injection) act to keep $\mathrm{HCO}_{3}^{-}$as the dominant anion. The incongruent dissolution of carbonate minerals on the initial portion of the flowpath leads to $\mathrm{Ca}^{2+}$ dominating the cation chemistry; because the silicate hydrolysis reactions on the latter portion of the flowpath are acting on sediments derived from rhyolitic rocks and on basalts or clays produced from basalt weathering, $\mathrm{Na}^{+}$and $\mathrm{Mg}^{2+}$ will be the main cations introduced to the water (Earman et al. 2005). The decrease in $\mathrm{Ca}^{2+}$ from the initial to the latter portion of the flowpath is likely the result of calcite precipitation due to the common ion effect resulting from $\mathrm{HCO}_{3}^{-}$ derived from injection of $\mathrm{CO}_{2}$.

Compared to well water, spring water has elevated concentrations of $\mathrm{Mg}^{2+}$. Other than the basalts, lithologic logs and geologic maps show no reasonable source material in the basin for the high magnesium values. Valley floor springs are present only near the center of the basin. In this area, basalts are present only at relatively shallow depths; the wells in this area yield water from below the depths at which basalts are present, but spring water must have either flowed through fractures in the basalts or been in close contact with basalts prior to discharge. Geochemical modeling supports this conceptual model for elevated $\mathrm{Mg}^{2+}$ in spring water (Earman et al. 2005), and other ground waters where basalts are present show elevated $\mathrm{Mg}^{2+}$ concentrations (e.g., Hufen et al. 1974; Wood and Low 1986; Shevenell et al. 1987; Maurer and Welch 2001; Aiuppa et al. 2003).

\section{Pumping Tests}

In addition to the estimates of hydraulic conductivity derived from ground water ages, pumping tests were used to determine aquifer properties. A series of "pumping" tests were carried out in the main aquifer in January 2001. Rather than actually pumping water from wells to perturb the aquifer, natural discharge from flowing artesian wells in the SBNWR (Figure 2A) was used. Although not truly pumped, the discharge from these wells impacts the aquifer in the same manner as a pumped well, so changes in head experienced by neighboring wells can be analyzed as a function of discharge from the flowing artesian well using traditional pumping test analysis methods. Both drawdown and recovery data were analyzed with AQTESOLV software (HydroSOLVE Inc. 2000) using the Theis method (Batu 1998). An assumption underlying the mathematics of the Theis method is that the pumping well draws water from the entire thickness of the aquifer. Although none of the "pumping" wells were fully penetrating, we believe they do interrogate a significant portion of the aquifer; the degree of agreement between the data and type curves supported the idea that lack of complete penetration did violate the Theis method assumptions enough to yield significant error. Transmissivity values obtained from analysis of seven pumping tests ranged from $5.3 \times 10^{-4}$ to $3.6 \times$ $10^{-3} \mathrm{~m}^{2} / \mathrm{s}$, with a mean value of $2.5 \times 10^{-3} \mathrm{~m}^{2} / \mathrm{s}$, and all but one value falling between $1.8 \times 10^{-3}$ and $3.6 \times 10^{-3}$ $\mathrm{m}^{2} / \mathrm{s}$. Using a value for aquifer thickness of $275 \mathrm{~m}$ based on our model of basin structure (there are no fully penetrating wells in the area that could be used to obtain an actual value for aquifer thickness), these values were converted to hydraulic conductivities ranging from $1.9 \times$ $10^{-6}$ to $1.3 \times 10^{-5} \mathrm{~m} / \mathrm{s}$, with a geometric mean of $7.1 \times$ $10^{-6} \mathrm{~m} / \mathrm{s}$. Slug tests in the local unconfined aquifer in the basin center were conducted by Davis et al. (1997), yielding a geometric mean conductivity of $4.9 \times 10^{-6} \mathrm{~m} / \mathrm{s}$, with low and high values of $5.0 \times 10^{-7}$ and $2.7 \times 10^{-5} \mathrm{~m} / \mathrm{s}$.

An aquifer test was conducted in the main aquifer at the SBNWR (where flowing artesian conditions prevail) in December 2002. Pumping was initiated in the Twin 2 well (Figure S1) at 14:10 on December 2, 2002, with the pumping rate held constant at $1.25 \mathrm{~m}^{3} / \mathrm{min}$ for $4320 \mathrm{~min}$. The pump was installed to a depth of $104 \mathrm{~m}$ below top of casing with the flow rate monitored via an impeller type flowmeter. Hydraulic parameters were estimated by evaluating water level responses from four nearby monitor wells located within the SBNWR boundaries using the Theis and Cooper-Jacob methods for confined aquifers. The wells monitored for water level responses at various distances from the pumped well were Twin 1 at $68 \mathrm{~m}$, Oasis at $575 \mathrm{~m}$, East Border at $724 \mathrm{~m}$, and Bunting at $1637 \mathrm{~m}$.

The results of the analyses for each of the four observation wells monitored during the aquifer test are given in Table 2; two sample plots are shown in Figure S2. Estimates for transmissivity for the SBNWR as a whole range from $1.91 \times 10^{-3}$ to $3.49 \times 10^{-3} \mathrm{~m}^{2} / \mathrm{s}\left(6.95 \times 10^{-6} \mathrm{~m} / \mathrm{s}\right.$ to $1.27 \times 10^{-5} \mathrm{~m} / \mathrm{s}$ based on the assumed aquifer thickness of $275 \mathrm{~m}$ ), and values for storativity range from $1.1 \times 10^{-3}$ to $1.9 \times 10^{-4}$. Geometric mean values of transmissivity for individual wells are as follows: $2.92 \times$ $10^{-3} \mathrm{~m}^{2} / \mathrm{s}$ for East Border, $1.93 \times 10^{-3} \mathrm{~m}^{2} / \mathrm{s}$ for Twin 1 , $2.51 \times 10^{-3} \mathrm{~m}^{2} / \mathrm{s}$ for Oasis, and $2.15 \times 10^{-3} \mathrm{~m}^{2} / \mathrm{s}$ for Bunting $\left(1.06 \times 10^{-5} \mathrm{~m} / \mathrm{s}, 7.02 \times 10^{-6} \mathrm{~m} / \mathrm{s}, 9.13 \times\right.$ $10^{-6} \mathrm{~m} / \mathrm{s}$, and $7.82 \times 10^{-6} \mathrm{~m} / \mathrm{s}$, respectively, assuming a $275-\mathrm{m}$ aquifer thickness). The estimates for the four monitor wells show a geometric mean for transmissivity of $2.23 \times 10^{-3} \mathrm{~m}^{2} / \mathrm{s}\left(8.12 \times 10^{-6} \mathrm{~m} / \mathrm{s}\right.$ for a $275 \mathrm{~m}$ thick aquifer) and $4.5 \times 10^{-4}$ for storativity from the Theis analyses (averaged from the drawdown and recovery methods), and a geometric mean for transmissivity of 
Table 2

Aquifer Parameters Calculated for Various Wells during the Aquifer Test Conducted in December 2002

\begin{tabular}{|lccccc|}
\hline & $\begin{array}{c}\text { Transmissivity: } \\
\text { Theis Drawdown } \\
\left(\mathbf{m}^{2} / \mathbf{s}\right)\end{array}$ & $\begin{array}{c}\text { Transmissivity: } \\
\text { Theis Recovery } \\
\left(\mathbf{m}^{2} / \mathbf{s}\right)\end{array}$ & $\begin{array}{c}\text { Transmissivity: } \\
\text { Cooper-Jacob } \\
\text { Drawdown }\left(\mathbf{m}^{2} / \mathbf{s}\right)\end{array}$ & $\begin{array}{c}\text { Storativity: } \\
\text { Theis Drawdown }\end{array}$ & $\begin{array}{c}\text { Storativity: } \\
\text { Cooper-Jacob } \\
\text { Drawdown }\end{array}$ \\
\hline East Border & $2.71 \times 10^{-3}$ & $2.62 \times 10^{-3}$ & $3.49 \times 10^{-3}$ & $1.1 \times 10^{-3}$ & $7.3 \times 10^{-4}$ \\
Twin 1 & $1.91 \times 10^{-3}$ & $1.94 \times 10^{-3}$ & $1.94 \times 10^{-3}$ & $2.2 \times 10^{-4}$ & $1.9 \times 10^{-4}$ \\
Oasis & $2.36 \times 10^{-3}$ & $2.11 \times 10^{-3}$ & $3.18 \times 10^{-3}$ & $5.0 \times 10^{-4}$ & $3.6 \times 10^{-4}$ \\
Bunting & $2.15 \times 10^{-3}$ & - & - & $3.3 \times 10^{-4}$ & - \\
Geometric mean & $\mathbf{2 . 2 6} \times \mathbf{1 0}^{-3}$ & $\mathbf{2 . 2 1} \times \mathbf{1 0}^{-\mathbf{3}}$ & $\mathbf{2 . 7 8} \times \mathbf{1 0}^{-\mathbf{3}}$ & $\mathbf{4 . 5} \times \mathbf{1 0}^{-\mathbf{4}}$ & $\mathbf{3 . 7}^{-\mathbf{3}} \times \mathbf{1 0}^{-\mathbf{4}}$ \\
\hline
\end{tabular}

$2.78 \times 10^{-3} \mathrm{~m}^{2} / \mathrm{s}\left(1.01 \times 10^{-5} \mathrm{~m} / \mathrm{s}\right.$ for a $275-\mathrm{m}$ thick aquifer) and $3.7 \times 10^{-4}$ for storativity from the CooperJacob analysis. As with the Theis method, the CooperJacob method assumes a fully penetrating well. In addition, it assumes that the value of the $u$ term from the Theis equation is small $(<0.01)$. For Twin 1 well, this criterion was met at the end of the test; for Oasis, the value of $u$ was 0.07 , yielding an error of about $2 \%$ (Kruseman and de Ridder 2000); East Border and Bunting had values of 0.2 and 0.4 (respectively), suggesting errors greater than $10 \%$. The variation in estimates for hydraulic parameters among the four wells monitored can be directly attributed to the heterogeneity of the aquifer materials.

The mean values for hydraulic conductivity from the pumping tests $\left(8.12 \times 10^{-6} \mathrm{~m} / \mathrm{s}\right.$ for Theis analyses and $1.01 \times 10^{-5} \mathrm{~m} / \mathrm{s}$ for Cooper-Jacob analyses) and the tests using flowing artesian wells as pumped wells $\left(9.1 \times 10^{-6} \mathrm{~m} / \mathrm{s}\right)$ are quite similar to the mean value for conductivity derived from ${ }^{14} \mathrm{C}$ ages of $2 \times 10^{-5} \mathrm{~m} / \mathrm{s}$.

\section{Ground Water Flux}

Darcy's Law was used to calculate ground water flux across the international border through the main aquifer. The transboundary flux represents a first-cut estimate of ground water recharge in the U.S. portion of the basin (the greatest density of wells is in the area near the international border, thus the area has the best data for calculating hydraulic gradient); it does not account for pumping or natural forms of discharge, and is thus a low-end estimate. In addition, because pumping in Mexico for direct water supply to Agua Prieta or to provide irrigation water for crops to supply the growing population could have a significant impact on the water supply of the threatened and endangered fishes at the SBNWR, knowledge of the transboundary flux is important. The mean transmissivity value from the pumping tests $\left(2.4 \times 10^{-3} \mathrm{~m}^{2} / \mathrm{s}\right)$ was used to account for both the $K$ term and the aquifer thickness; the width of the aquifer at the international border $(8420 \mathrm{~m})$ and the hydraulic gradient calculated from wells in the border vicinity $\left(3.32 \times 10^{-3}\right.$, based on a head difference of $7.7 \mathrm{~m}$ and a horizontal separation of $2321 \mathrm{~m}$ ) were also used. The flux was calculated to be $2 \times 10^{6} \mathrm{~m}^{3} /$ year, intermediate between the two known prior estimates of $6.2 \times 10^{5}$ and $6.8 \times 10^{6} \mathrm{~m}^{3} /$ year (Anderson et al. 1992; Hawley et al. 2000). Upward flux from the main aquifer to the local aquifer across the local confining unit is estimated to be $4 \times 10^{3} \mathrm{~m}^{3} /$ year, based on an area of
$9.8 \times 10^{7} \mathrm{~m}^{2}$ for the confining clays, a measured hydraulic gradient of 0.25 between the main aquifer and the local aquifer, and a confining unit hydraulic conductivity of $5 \times 10^{-12} \mathrm{~m} / \mathrm{s}$ (the modal conductivity value for clay reported by Freeze and Cherry [1979]). No attempt was made to quantify total discharge via wells or springs, so the transboundary flow represents a low-end bound for recharge in the U.S. portion of the basin. The sparse population, limited use of most wells, and the low discharge of most springs in the basin (all known springs in the basin were visited; observations suggest that with the exception of springs discharging water from the shallow aquifer, total annual basin-floor spring discharge is several orders of magnitude lower than the flux across the international border).

\section{Potential Impacts of Regional Population Growth}

The population in the Douglas Basin was 28,500 in 2003; at that time, annual demand for ground water was $1.2 \times 10^{8} \mathrm{~m}^{3} /$ year (State of Arizona 2006a). Based on the projected 2050 population of 36,500 (State of Arizona 2006a) and the 2003 ground water demand rate, the water demand at that time will be $1.5 \times 10^{8} \mathrm{~m}^{3} / \mathrm{year}$, an increase of $3.0 \times 10^{7} \mathrm{~m}^{3} /$ year. However, increased demands might not be able to be accommodated by additional pumping of ground water in the Douglas Basin because of water quality issues (State of Arizona 2006b). In addition, the Douglas Basin is classified by the State of Arizona as an "irrigation nonexpansion area," meaning that no increase in irrigated acreage is permitted (State of Arizona 2006b). As a result, demand for municipal supply and additional agricultural land (and resultant pumping of ground water) could be met using water resources from the San Bernardino Valley. Because the forecast increase in demand for Douglas Basin is 15 times the transboundary flux in the San Bernardino Valley, satisfying even a small portion of increased demand for Douglas Basin from the San Bernardino Valley would have serious consequences for the San Bernardino Aquifer. Similarly, population growth or expanded industrial or agricultural activity in Agua Prieta could cause increased demand for water, and water quality issues in the Agua Prieta area could lead to utilization of water from San Bernardino Valley. In 1995, water use in Agua Prieta was approximately 190 L per person per day (National Institute of Statistics Geography and Information [INEGI]/National Institute of Ecology [INE]/SEMARNAP 1999), meaning 
that providing a supply adequate for 29,000 people would exceed the annual transboundary flux in the San Bernardino Valley. Based on the population growth from 1980 to 2005, Agua Prieta gains this many residents every 4.2 years.

Using the San Bernardino aquifer to meet even small portions of the demand for water in neighboring basins due to supply and/or quality issues could easily result in pumping volumes greater than annual recharge to the aquifer. If such pumping occurs, springs and natural wetlands in the basin center that support wildlife would likely dry and flowing artesian conditions could be lost for wells on the SBNWR that supply water to maintain the threatened and endangered fishes there.

\section{Comparison of San Bernardino Hydrogeology to That of Neighboring Basins}

The San Bernardino Valley has four neighboring basins in the United States (Figure 1). These basins were all formed by Basin and Range extension, and the highlands bounding them are mineralogically similar to those bounding the San Bernardino Valley. Based on the similar modes of formation, ages, and source materials for the basins' fill, one might expect ground water quality and chemical evolution to be similar in the San Bernardino Valley and its neighboring basins. In fact, the chemical evolution of San Bernardino ground water is distinct (Figure 6), as are some other aspects of the basin's hydrogeology. We hypothesized that the major hydrogeologic differences between the San Bernardino Valley and its neighbors are related to tectonics, namely the presence of the accommodation zone in the San Bernardino Valley (none of the neighboring basins contain an accommodation zone). These differences and their relation to the accommodation zone are discussed subsequently.

\section{Tectonic Influences on Water Chemistry}

\section{Presence of Evaporite Deposits}

The presence or absence of evaporite deposits can have a significant impact on water quality. Because most evaporite minerals are very soluble (Hem 1992), interaction with evaporites can significantly increase dissolved solids relative to water that has not encountered evaporites. All the San Bernardino Valley's neighboring basins contain evaporite deposits (Cushman et al. 1947; Coates and Cushman 1955; Spiegel 1957; Schreiber 1978). The San Bernardino Valley has no known evaporites, as indicated by the mapping of Drewes (1980), Dirección General de Geográfica del Territorio Nacional (1982), and Biggs et al. (1999), and borehole lithologic data. San Bernardino water has lower dissolved solids levels than the neighboring basins (Barnes 1991; Schwab 1992; Oram 1993; Rascona 1993; Hawley et al. 2000), in large part due to evaporites being present in the neighboring basins but not in San Bernardino Valley. Although values of total dissolved solids (TDS) content of ground water are not available for all the neighboring basins, EC typically scales with TDS (Hem 1992), and EC values are available for all basins. The maximum value measured in the SBB $(1763 \mu \mathrm{S} / \mathrm{cm})$ is significantly lower than the maximum values measured in neighboring basins, which range from 2380 to $7800 \mu \mathrm{S} / \mathrm{cm}$ (Barnes 1991; Schwab 1992; Oram 1993; Rascona 1993; Hawley et al. 2000).

The formation of significant evaporite deposits typically requires an internally drained basin. We hypothesize that the San Bernardino Valley lacks evaporite deposits because it has been externally drained, as opposed to the neighboring basins, which have been internally drained.

Crustal buoyancy due to magmatism associated with the accommodation zone kept subsidence to a minimum in the San Bernardino Valley during the Oligocene and early/mid-Miocene. However, tectonic activity has since increased and the basin is now more tectonically active than the neighboring basins. The most dramatic evidence is an 1887 earthquake (estimated Richter magnitude 7.2) along the Pitaycachi fault on the eastern margin of the basin in Mexico (DuBois and Smith 1980). Lynch's (1972) observations of entrenched alluvial fan deposits in the Chiricahuas are evidence of present-day uplift along the mountain-front fault in the U.S. portion of the basin; Pearthree (1986) indicates that the San Bernardino Valley has been among the most tectonically active in southeastern Arizona during the late Quaternary and describes significant fault scarps as being between 3000 and 10,000 years old.

Because the loss of crustal buoyancy and increased tectonic activities have occurred over the last $10 \mathrm{Ma}$, the majority of subsidence in the San Bernardino Valley has taken place during that time, a period in which the neighboring basins have been relatively inactive (Morrison 1991). Most of the geologically recent subsidence has occurred in the southern portion of the basin. For instance, the 1887 event on the Pitaycachi fault caused up to $5 \mathrm{~m}$ of offset on the mountain-front fault, and aerial observation in 1972 revealed the presence of numerous associated scarps representing active mountain-front faulting over the past few thousand years (Stover and Coffman 1993); a magnitude 4.2 normal fault event in May 1989 also occurred near the Pitaycachi fault in the southern portion of the basin (Wallace and Pearthree 1989; Wallace 1990). A number of smaller events in May and June 1989 all took place in the Sonoran portion of the basin (Wallace and Pearthree 1989). While the observations of Lynch (1972) and Pearthree (1986) indicate that the northern portion of the basin has been seismically active in the geologically recent past, the southern portion of the basin appears to have been more active and experienced significantly greater subsidence.

Lynch (1978) found that the main channel of the drainage system in the San Bernardino Valley is currently eroding headward; he surmises that this is a (geologically) recent development brought about by a tectonically induced change in base level. Because the southern portion of the San Bernardino Valley experienced more subsidence than the northern portion in the late Quaternary, local base level for the northern portion of the basin has dropped, which has led to increased stream downcutting in the northern portion of the basin. Neighboring basins appear to have had less tectonic activity in recent 
geologic time, and because they lack accommodation zones that would allow such differential subsidence, tectonic activity did not preferentially increase stream downcutting and drainage. As a result, the neighboring basins have been internally drained, while San Bernardino Valley has been externally drained.

\section{Influence of Magmatic $\mathrm{CO}_{2}$ on Paleochemistry and Types of Evaporites Observed Today}

The impact of the accommodation zone-related $\mathrm{CO}_{2}$ on water chemistry is observable today, but because magmatism in San Bernardino Valley associated with the accommodation zone began approximately 3.6 Ma ago, it has likely been affecting water chemistry for some time.

Although there are no known evaporite minerals in the San Bernardino Valley, Earman et al. (2005) use the USGS's computer code SNORM (Bodine and Jones 1986) to show that if San Bernardino water were evaporated, approximately $60 \%$ (by mass) of the resultant evaporite mineral assemblage would be trona $\left[\mathrm{Na}_{3}\left(\mathrm{CO}_{3}\right)\left(\mathrm{HCO}_{3}\right)\right.$. $\left.2\left(\mathrm{H}_{2} \mathrm{O}\right)\right]$. None of the neighboring basins have any significant sodium carbonate evaporites present, and SNORM modeling confirms that water from these basins would yield, at most, negligible quantities of sodium carbonate minerals upon evaporation. Similar modeling was conducted for waters in the Sierra Nevada, all of which are exposed to similar lithologies (mineralogically similar to that of the highlands surrounding the San Bernardino Valley and its neighboring basins) but are either impacted or unimpacted by magmatic $\mathrm{CO}_{2}$ injection. A distinct correlation was found: water receiving $\mathrm{CO}_{2}$ injection would yield significant amounts of trona upon evaporation, but water unimpacted by magmatic $\mathrm{CO}_{2}$ would yield calcite/gypsum/halite/apthitalite assemblages, but no trona.

This implies that if San Bernardino's neighboring basins contained accommodation zones that caused $\mathrm{CO}_{2}$ injection, their water chemistry would likely have been $\mathrm{Na}^{+}-\mathrm{HCO}_{3}^{-}$dominated, and trona deposits would have formed rather than the calcite/gypsum/halite assemblages observed. If that had been the case, present-day basincenter water of the neighboring basins would have a similar sodium bicarbonate signature to that found in San Bernardino, rather than developing sulfate or chloride anion dominance.

\section{Presence of Basalts as a Major Component of Basin Fill}

Basalts associated with the accommodation zone are ubiquitous in the southern two-thirds of the northern portion of the San Bernardino Valley but are not significant components of the fill in neighboring basins. This is important to ground water quality because basalts are a significant source of magnesium (Hufen et al. 1974; Wood and Low 1986; Shevenell et al. 1987; Maurer and Welch 2001; Aiuppa et al. 2003). The alluvial fill material in neighboring basins is mineralogically similar to that interbedded with the basalts in the San Bernardino Valley-it is derived from mountain ranges that are predominantly composed of rhyolitic/granitic rocks and some sedimentary units. These sedimentary rocks do contain some dolomites (which could provide $\mathrm{Mg}^{2+}$ ), but dolomites are a minor component compared to limestone, sandstone, and siltstone. As a result, neighboring basins do not contain material that can contribute significant amounts of magnesium to ground water.

Ground water in the neighboring basins tends to develop cation signatures dominated by $\mathrm{Na}^{+}$from rhyolitic sediments but with little discernable influence from $\mathrm{Mg}^{2+}$ (Figure 6). As ground water moves through the San Bernardino Valley, $\mathrm{Na}^{+}$increases, but $\mathrm{Mg}^{2+}$ exerts a strong influence on the cation signature due to interaction with basalts.

\section{Tectonic Influence on Other Hydrogeologic Properties}

The thickness of basin fill in the San Bernardino Valley is small compared to that in neighboring basins - the maximum thickness of basin fill in the San Bernardino Valley is $781 \mathrm{~m}$, while the average thickness of basin fill in southeastern Arizona is $1600 \mathrm{~m}$ (Scarborough and Peirce 1978). The thin basin fill in the San Bernardino Valley is the result of crustal buoyancy during the Oligocene and early/mid-Miocene produced by magmatism associated with the accommodation zone. While the neighboring basins experienced significant subsidence and infilling during the Oligocene and early/mid-Miocene, this buoyancy inhibited subsidence in the San Bernardino Valley (Drewes 1981).

\section{Basin Storage and Water Available for Use}

The fact that the maximum thickness of San Bernardino's alluvial fill is less than half the average thickness of alluvial fill in southeastern Arizona basins impacts the volume of water that can be stored in the basin's main aquifer and thus the amount potentially available for use. Assuming identical porosities, the thin San Bernardino aquifer will store less water per unit surface area than the thicker aquifers in the neighboring basins. In turn, if gravity drainage properties are similar, the thin San Bernardino aquifer would be able to supply a significantly lower total volume of water than the aquifers in the neighboring basins.

\section{Ground Water Circulation and Age}

Basin depth affects the depth of circulation of water. A deep basin offers the opportunity for deep flowpaths with much longer travel distances than shallow flowpaths (e.g., Tòth 1962). Deep and long flowpaths thus provide the opportunity for increased water residence time compared to relatively shallow and short flowpaths.

Ground water ages for the San Bernardino Valley show that water in the basin center is approximately 6500 years old. For basins in southeastern Arizona with fill depth similar to the neighboring basins, reported maximum ages range from "greater than 10,000 years" (with two corrected samples from that study reflecting ages above 15,000 years) to 14,600 years (Campana 1987; Robertson 1991; Wahi 2005). Smalley (1983) reports ${ }^{14} \mathrm{C}$ values for ground water in the Gila subbasin of the Safford Basin but does not report ages based on the data. We analyzed the data using the method of Fontes and Garnier (1979) and found that the maximum 
ground water age was more than 20,000 years. In general, ground water in alluvial aquifers of southeastern Arizona basins is of the same age range seen in the San Bernardino Valley if the water has experienced only shallow circulation; water that has experienced deep circulation is older (e.g., Wahi 2005).

\section{Conclusions}

Based on the results of a study using multiple complementary methods of investigation, several major hydrologic properties (including chemical evolution of water, dissolved ion concentration, volume of water stored per unit area of aquifer, and water residence time) of the San Bernardino Valley aquifer differ markedly from those of its neighboring basins, even though all the basins have common ages and modes of formation and are bounded by highlands of similar lithology. The San Bernardino Valley has hydrologic properties distinct from those of its neighboring basins because its geology is unique when compared to that of the neighboring basins; all the major geologic differences are due to the presence of a magmatically active accommodation zone. Important influences associated with the accommodation zone include extensive basaltic volcanism, thin basin fill due to crustal buoyancy, and recent tectonic activity increasing stream downcutting. These facts lead us to propose that other basins with magmatically active regional segmentation boundaries or other similar tectonic features may likewise have similarly distinctive hydrologic properties, especially water chemistry, in terms of both chemical signature and TDS. This is similar to the hypotheses of Newell et al. (2005) and Earman et al. (2005) regarding the potential impacts of mantle fluids on aquifer chemistry. The geological differences and the resultant chemical differences between the San Bernardino Valley and its neighboring basins may serve as a model for how chemical evolution of ground water in other magmatically active accommodation-zone basins (more than 60 of which are identified in the western United States) differs from that of their neighbors.

Aside from limited zones where focused recharge from valley floor precipitation occurs, the main aquifer of the San Bernardino Valley receives its recharge from the bounding mountain ranges. Approximately twothirds of the recharge appears to be derived from the Chiricahua Mountains, which are the highest bounding range. Precipitation falling at or above $2300 \mathrm{~m}$ appears to account for the majority of recharge from the Chiricahuas, and snowmelt is responsible for the majority of recharge. Mean values for hydraulic conductivity for the aquifer from pumping tests and a method using ${ }^{14} \mathrm{C}$ ages range from $8.18 \times 10^{-6}$ to $2 \times 10^{-5} \mathrm{~m} / \mathrm{s}$. The flux of water across the international border, calculated to be $2 \times 10^{5} \mathrm{~m}^{3} /$ year, gives a low-end estimate for annual recharge in the U.S. portion of the basin. Because ground water in adjacent basins is of poorer quality than that in San Bernardino Valley, San Bernardino ground water may be viewed as a desirable source of supply for nearby cities. It appears that providing even a small portion of the water demand for surrounding areas would cause ground water mining, with potential negative consequences for the viability of springs and wetlands, and the water supply that provides habitat for threatened and endangered species.

The level of insight into the hydrogeology of the San Bernardino Valley is related to the application of a number of complementary methods, including hydrochemistry, isotope hydrology, aquifer testing, geophysics, and analysis of geologic maps and lithologic logs. Each method provides some information on its own, but by combining many approaches, a much better understanding of basin hydrogeology was developed than would have been possible using fewer methods.

\section{Supplementary material}

The following supplementary material is available for this article:

Figure S1. Locations of selected wells on the SBNWR (Figure 2A in the main article).

Figure S2. Sample plots showing results of aquifer pumping test at the SBNWR. Observed values are shown as black crosses; aquifer test type curves are shown in gray. A: Drawdown in Twin 1 from pumping Twin 2. B. Recovery of East Border after cessation of pumping at Twin 2. The parameter $t / t^{\prime}$ represents the total time elapsed since pumping was initiated $(\mathrm{t})$ divided by the time elapsed since pumping ceased and recovery began $\left(\mathrm{t}^{\prime}\right)$.

Table S1. Data for Water Chemistry in the San Bernardino Valley and Vicinity.

This material is available as part of the on-line article from: http://www.blackwell-synergy.com/doi/abs/10.1111/ j.1745-6584.2007.00320.x

(This link will take you to the article abstract.)

Please note: Blackwell Publishing is not responsible for the content or functionality of any supplementary materials supplied by the authors. Any queries (other than missing material) should be directed to the corresponding author for the article.

\section{Acknowledgments}

Major funding for this research was provided by the U.S. Fish and Wildlife Service. The dissolved gas sampling and analysis were funded by the Sustainability of semi-arid Hydrology and Riparian Areas (SAHRA) Science and Technology Center of the National Science Foundation (NSF agreement No. EAR-9876800). Logistical and scientific assistance was provided by numerous U.S. Fish and Wildlife Service personnel, especially Steve Cullinan, Nina King, Matt Magoffin, Gary Shellhorn, Paul Tashjian, and Tony Velasco. We appreciate the assistance of the USDA Forest Service, especially Louie Pope; the Arizona Geological Survey, especially Tom Biggs, Phil Pearthree, and Steve Skotnicki, and the numerous landowners/leaseholders who allowed us to sample from wells on land they own or manage. We appreciate comments from Alan Fryar, James Mayer, and two anonymous reviewers, which led to major improvements in the manuscript. Figures 1 and 7 reprinted from Earman, S., F.M. 
Phillips, and B.J.O.L. McPherson. The role of "excess" $\mathrm{CO}_{2}$ in the formation of trona deposits. Applied Geochemistry 20, 2217-2232, Copyright 2005, with permission from Elsevier.

\section{References}

Aiuppa, A., S. Bellomo, L. Brusca, W. D'Alessandro, and C. Federico. 2003. Natural and anthropogenic factors affecting groundwater quality of an active volcano (Mt. Etna, Italy). Applied Geochemistry 18, no. 6: 863-882.

Aldrich, M.J. Jr., and W.A. Laughlin. 1984. A model for the tectonic development of the southeastern Colorado Plateau boundary. Journal of Geophysical Research 89, no. B12: 10207-10218.

Anderson, O.J., G.E. Jones, and G.N. Green. 1997. Geologic map of New Mexico. USGS Open-File Report 97-52. Reston, Virginia: USGS.

Anderson, T.W., G.W. Freethey, and P. Tucci. 1992. Geohydrology and water resources of alluvial basins in south-central Arizona and parts of adjacent states. USGS Professional Paper 1406-B. Reston, Virginia: USGS.

Barnes, R.L. 1991. Map showing groundwater conditions in the San Simon sub-basin of the Safford Basin, Graham and Cochise counties, Arizona, Hidalgo County, New Mexico1987. Hydrologic Map Series Report Number 19. Phoenix, Arizona: Arizona Department of Water Resources.

Batu, V. 1998. Aquifer Hydraulics: A Comprehensive Guide to Hydrogeologic Data Analysis. New York: John Wiley \& Sons Inc.

Biggs, T.H., R.S. Leighty, S.J. Skotnicki, and P.A. Pearthree. 1999. Geology and geomorphology of the San Bernardino Valley, southeastern Arizona. Open-File Report 99-19. Tucson, Arizona: Arizona Geological Survey.

Bodine, M.W. Jr., and B.F. Jones. 1986. THE SALT NORM: A quantitative chemical-mineralogical characterization of natural waters. USGS Water Resources Investigations Report 86-4086. Reston, Virginia: USGS.

Campana, M.E. 1987. Generation of ground-water age distributions. Ground Water 25, no. 1: 51-58.

Clark, I., and P. Fritz. 1997. Environmental Isotopes in Hydrogeology. Boca Raton, Florida: Lewis Publishers.

Coates, D.R., and R.L. Cushman. 1955. Geology and groundwater resources of the Douglas Basin, Arizona. USGS Water-Supply Paper 1354. Reston, Virginia: USGS.

Coleman, M.L., T.J. Shepherd, J.J. Durham, J.E. Rouse, and G.R. Moore. 1982. Reduction of water with zinc for hydrogen isotope analysis. Analytical Chemistry 54, no. 7: 993-995.

Cushman, R.L., R.S. Jones, and J.D. Hem. 1947. Geology and ground-water resources of the San Simon Basin, Cochise and Graham counties, Arizona. USGS Open-File Report (unnumbered). Reston, Virginia: USGS.

Davis, L.A., I. Thomas Maddock, and R.M. Nish. 1997. Ground-water flow and interaction with surface water in San Bernardino Valley, Cochise County, Arizona and Sonora, Mexico. Report No. 97-030. Phoenix, Arizona: University of Arizona Department of Hydrology and Water Resources.

Dirección General de Geográfica del Territorio Nacional. 1982. Agua Prieta H12-3, Carta Geological. Escala 1:250,000. Dirección General de Geográfica del Territorio Nacional.

Drewes, H.A. 1981. Tectonics of southeastern Arizona. USGS Professional Paper 1144. Reston, Virginia: USGS.

Drewes, H. 1980. Tectonic map of southeast Arizona. USGS Miscellaneous Investigations Series Map I-1109. Reston, Virginia: USGS.

DuBois, S.M., and A.W. Smith. 1980. The 1887 earthquake in San Bernardino Valley, Sonora: Historic accounts and intensity patterns in Arizona. Special Paper No. 3. Phoenix, Arizona: State of Arizona Bureau of Geology and Mineral Technology. du Bray, E.A., J.S. Pallister, and D.B. Yager. 1997. Geologic map of the Turkey Creek caldera, Chiricahua Mountains, Cochise County, Arizona. USGS Miscellaneous Investigations Series Map I-2544. Reston, Virginia: USGS.

Earman, S. 2004. Groundwater recharge and movement through mountain-basin systems of the Southwest: A case study in the Chiricahua Mountains-San Bernardino Valley system, Arizona and Sonora. Ph.D. diss., New Mexico Institute of Mining and Technology, Socorro, New Mexico.

Earman, S., A.R. Campbell, B.D. Newman, and F.M. Phillips. 2006. Isotopic exchange between snow and atmospheric water vapor: Estimation of the snowmelt component of groundwater recharge in the southwestern United States. Journal of Geophysical Research 111, D9: D09302, doi: 10.1029/2005JD006470.

Earman, S., F.M. Phillips, and B.J.O.L. McPherson. 2005. The role of "excess" $\mathrm{CO}_{2}$ in the formation of trona deposits. Applied Geochemistry 20, no. 12: 2217-2232, doi:10.1016/ j.apgeochem.2005.08.007.

Faulds, J.E., and R.J. Varga. 1998. The role of accommodation zones and transfer zones in the regional segmentation of extended terranes. In Accommodation Zones and Transfer Zones: The Regional Segmentation of the Basin and Range Province, ed. J.E. Faulds and J.H. Stewart, 1-45. Special Paper 323. Boulder, Colorado: Geological Society of America.

Fontes, J.-C., and J.-M. Garnier. 1979. Determination of the initial ${ }^{14} \mathrm{C}$ activity of the total dissolved carbon: A review of the existing models and a new approach. Water Resources Research 15, no. 2: 399-413.

Hawley, J.W., B.J. Hibbs, J.F. Kennedy, B.J. Creel, M.D. Remmenga, M. Johnson, M.M. Lee, and P. Dinterman. 2000. Trans-international boundary aquifers in southwestern New Mexico. Technical Completion Report. Las Cruces, New Mexico: New Mexico Water Resources Research Institute.

Hem, J.D. 1992. Study and interpretation of the chemical characteristics of natural water. USGS Water-Supply Paper 2254. Reston, Virginia: USGS.

Hirschberg, D.M., and G.S. Pitts. 2000. Digital geologic map of Arizona. USGS Open-File Report 00-409. Reston, Virginia: USGS.

Hufen, T.H., R.W. Buddemeier, and L.S. Lau. 1974. Isotopic and chemical characteristics of high-level groundwaters on Oahu, Hawaii. Water Resources Research 10, no. 2: 366-370.

HydroSOLVE Inc. 2000. AQTESOLV for Windows Users Guide. Reston, Virginia: HydroSOLVE Inc.

Kruseman, G.P., and N.A. de Ridder. 2000. Analysis and Evaluation of Pumping Test Data, 2nd ed. Publication 47. Wageningen, The Netherlands: International Institute for Land Reclamation and Improvement (ILRI).

Longsworth, S.A. 1991. Geohydrology and chemical quality of ground water. San Bernardino National Wildlife Refuge, Arizona.USGS Water-Resources Investigations Report 904190.

Lynch, D.J. 1978. The San Bernardino volcanic field of southeastern Arizona. In Land of Cochise, Southeastern Arizona, Twenty-Ninth Field Conference Guidebook, ed. J.F. Callender, J.C. Wilt, and R.E. Clemons, 261-268. Socorro, New Mexico: New Mexico Geological Society.

Lynch, D.J. 1972. Reconnaissance geology of the Bernardino volcanic field, Cochise County, Arizona. M.S. thesis, University of Arizona, Tucson, Arizona.

Manning, A.H. 2002. Using noble gas tracers to investigate mountain-block recharge to an intermountain basin. Ph.D. diss., University of Utah, Salt Lake City, Utah.

Mao, J., R. Kerrich, H. Li, and Y. Li. 2002. High ${ }^{3} \mathrm{He} /{ }^{4} \mathrm{He}$ ratios in the Wangu gold deposit, Hunan Province, China: Implications for mantle fluids along the Tanlu deep fault zone. Geochemical Journal 36, no. 3: 197-208.

Mariner, R.H., J.B. Lowenstern, and G. Nimz. 2000. Isotopic composition of snow at Medicine Lake volcano, CA (USA) and implications for recharge to the $37 \mathrm{~m}^{3} \mathrm{~s}^{-1}$ Fall River 
Springs. Geological Society of America Abstracts with Programs 32, no. 7.

Maulé, C.P., D.S. Chanasyk, and K. Muelenbachs. 1994. Isotopic determination of snow-water contribution to soil water and groundwater. Journal of Hydrology 155, no. 1-2: 73-91.

Maurer, D.K., and A.H. Welch. 2001. Hydrogeology and geochemistry of the Fallon Basalt and adjacent aquifers, and potential sources of basalt recharge, in Churchill County, Nevada. USGS Water-Resources Investigations Report 014130. Reston, Virginia: USGS.

Morrison, R.B. 1991. Quaternary geology of the southern Basin and Range province. In Quaternary Nonglacial Geology: Conterminous U.S. Geology of North America, vol. K-2, ed. R.B. Morrison, 353-371. Boulder, Colorado: Geological Society of America.

National Institute of Statistics Geography and Information (INEGI)/National Institute of Ecology (INE)/SEMARNAP. 1999. Sustainable development indicators of Mexico. http:// www.onlinelearning.unu.edu/ayuquila/e-archive/18.pdf (accessed November 14, 2007).

Nelson, S.T., and D. Dettman. 2001. Improving hydrogen isotope ratio measurements for on-line chromium reduction systems. Rapid Communications in Mass Spectrometry 15, no. 23: 2301-2306.

Newell, D.L., L.J. Crossey, K.E. Karlstrom, T.P. Fischer, and D.R. Hilton. 2005. Continental-scale links between the mantle and groundwater systems of the western United States: Evidence from travertine springs and regional $\mathrm{He}$ isotope data. GSA Today 15, no. 12: 4-10.

Oram, P. III. 1993. Maps showing groundwater conditions in the Willcox Basin, Graham and Cochise counties, Arizona-1990. Hydrologic Map Series Report no. 25, 2 sheets with text. Phoenix, Arizona: Department of Water Resources.

Oxburgh, E.R., R.K. O’Nions, and R.I. Hill. 1986. Helium isotopes in sedimentary basins. Nature 324, 18/25 December: 632-635.

Pearthree, P.A. 1986. Late Quaternary faulting and seismic hazard in southeastern Arizona and adjacent portions of New Mexico and Sonora, Mexico. Open File Report 86-8. Tucson, Arizona: Arizona Geological Survey.

Phillips, F.M., M.K. Tansey, L.A. Peeters, S. Cheng, and A. Long. 1989. An isotopic investigation of groundwater in the central San Juan Basin, New Mexico: Carbon 14 dating as a basis for numerical flow modeling. Water Resources Research 25, no. 10: 2259-2273.

Plummer, L.N., E.C. Prestemon, and D.L. Parkhurst. 1991. An interactive code (NETPATH) for modeling net geochemical reactions along a flow path. USGS Water-Resources Investigations Report 91-4078. Reston, Virginia: USGS.

Plummer, L.N., J.F. Busby, R.W. Lee, and B.B. Hanshaw. 1990. Geochemical modeling of the Madison Aquifer in parts of Montana, Wyoming, and South Dakota. Water Resources Research 26, no. 9: 1981-2014.

Rascona, S.J. 1993. Maps showing groundwater conditions in the Douglas Basin, Cochise County, Arizona-1990. Hydrologic Map Series Report no. 26, 2 sheets with text. Phoenix, Arizona: Department of Water Resources.

Robertson, F.N. 1991. Radiocarbon dating in the San Pedro Valley, southeastern Arizona. Radiocarbon 33, no. 2: 236-237.

Scarborough, R.B., and H.W. Peirce. 1978. Late Cenozoic basins of Arizona, In Land of Cochise, Southeastern Arizona, New Mexico Geological Society Twenty-Ninth Field Conference Guidebook, ed. J.F. Callender, J.C. Wilt, and R.E. Clemons, 253-259. Socorro, New Mexico: New Mexico Geological Society.

Schreiber, J.F. Jr. 1978. Geology of the Willcox Playa, Cochise County, Arizona. In Land of Cochise, Southeastern Arizona, ed. J.F. Callender, J.C. Wilt, and R.E. Clemons, 277-282. Socorro, New Mexico: New Mexico Geological Society.
Schwab, K.J. 1992. Maps showing groundwater conditions in the San Bernardino Valley Basin, Cochise County, Arizona, and Hidalgo County, New Mexico-1991. Phoenix, Arizona: Department of Water Resources, 1 sheet with text.

Shevenell, L., F. Goff, F. Vuataz, P.E. Trujillo Jr., D. Counce, C.J. Janik, and W. Evans. 1987. Hydrogeochemical data for thermal and nonthermal waters and gases of the Valles Caldera-Southern Jemez Mountains region, New Mexico. Report LA-10923-OBES. Los Alamos, New Mexico: Los Alamos National Laboratory.

Simpson, E.S., D.B. Thorud, and I. Friedman. 1972. Distinguishing seasonal recharge to groundwater by deuterium analysis in southern Arizona. In World Water Balance: Proceedings of the Reading Symposium, July 1970, Volume 3, International Association of Scientific HydrologyUNESCO-WMO Studies and Reports in Hydrology, vol. 11; Publication No 94 of the International Association of Scientific Hydrology, pp. 623-633.

Smalley, R.C. 1983. An isotopic and geochemical investigation of the hydrogeologic and geothermal systems in the Safford Basin, Arizona. M.S. thesis, University of Arizona, Tucson, Arizona.

Socki, R.A., H.R. Karlsson, and E.K. Gibson Jr. 1992. Extraction technique for the determination of oxygen-18 in water using preevacuated glass vials. Analytical Chemistry 64, no. 7: 829-831.

Spiegel, Z. 1957. Geology: New Mexico State Engineer Office Technical Report No. 11. In Ground Water in Animas Valley, Hidalgo County, New Mexico, ed. H.O. Reeder, 9-12. Santa Fe, New Mexico: New Mexico State Engineer Office.

State of Arizona. 2006a. Arizona Water Resources and Issues (Report to the Border Governors Conference). http://www. tceq.state.tx.us/assets/public/compliance/R15_Harlingen/ US-MX\%20BGC\%20Water\%20table\%20documents/US\% 20States/Arizona/bgc_resources_and_issues_presentation_ final.ppt (accessed November 14, 2007).

State of Arizona. 2006b. Border Governor's Conference Water Table Summary of Water Management in Arizona. http:// www.tceq.state.tx.us/assets/public/compliance/R15_Harlingen/ US-MX\%20BGC\%20Water\%20table\%20documents/US\%20 States/Arizona/bcgwater_admin_overview.doc (accessed November 14, 2007).

Stewart, J.H., R.E. Anderson, J.J. Aranda-Gómez, L.S. Beard, G.H. Billingsley, S.M. Cather, J.H. Dilles, R.K. Dokka, J.E. Faulds, L. Ferrari, T.L.T. Grose, C.D. Henry, S.U. Janecke, D.M. Miller, S.M. Richard, P.D. Rowley, J. Roldán-Quintana, R.B. Scott, J.W. Sears, and V.S. Williams. 1998. Map showing Cenozoic tilt domains and associated structural features, western North America. In Accommodation Zones and Transfer Zones: The Regional Segmentation of the Basin and Range Province, ed. J.E. Faulds and J.H. Stewart. Boulder, Colorado: Geological Society of America, Special Paper 323.

Stover, C.W., and J.L. Coffman. 1993. Seismicity of the United States, 1568-1989 (Revised). USGS Professional Paper 1527. Reston, Virginia: USGS.

Tòth, J. 1962. A theory of groundwater motion in small drainage basins in central Alberta. Journal of Geophysical Research 67, no. 11: 4375-4387.

Wahi, A.K. 2005. Quantifying mountain system recharge in the Upper San Pedro Basin, Arizona, using geochemical tracers. M.S. thesis, University of Arizona, Tucson, Arizona.

Wallace, T.C. 1990. Summary of earthquake activity in Arizona for 1989; southern Arizona. Arizona Geology 20, no. 1: 6-7.

Wallace, T.C., and P.A. Pearthree. 1989. Recent earthquakes in northern Sonora. Arizona Geology 19, no. 3: 6-7.

Wertz, J.B. 1970. The Texas lineament and its economic significance in southeast Arizona. Economic Geology 65, no. 2: 166181. 
White, D.E., and G.A. Waring. 1963. Volcanic emanations. USGS Professional Paper 440-K. In Data of Geochemistry, Chap. K, 6th ed, M. Fleischer. USGS Professional Paper 440. Reston, Virginia: USGS.

Wilson, L.G., K.J. DeCook, and S.P. Neuman. 1980. Regional recharge research for Southwest alluvial basins. Unnumbered Report. Tucson, Arizona: Arizona Water Resources Research Center.
Winograd, I.J., A.C. Riggs, and T.B. Coplen, 1998. The relative contributions of summer and cool-season precipitation to groundwater recharge, Spring Mountains, Nevada, USA. Hydrogeology Journal 6, no. 1: 77-93.

Wood, W.W., and W.H. Low. 1986. Aqueous geochemistry and diagenesis in the eastern Snake River Plain aquifer system Idaho. Geological Society of America Bulletin 97, no. 12: $1456-1466$ 